NBER WORKING PAPER SERIES

\title{
DO UNIVERSITIES GENERATE AGGLOMERATION SPILLOVERS? EVIDENCE FROM ENDOWMENT VALUE SHOCKS
}

\author{
Shawn Kantor \\ Alexander Whalley \\ Working Paper 15299 \\ http://www.nber.org/papers/w15299
NATIONAL BUREAU OF ECONOMIC RESEARCH
1050 Massachusetts Avenue
Cambridge, MA 02138

August 2009

We thank the TIAA-CREF Institute Research Grant Program for financial support and Julie Cullen, Martin Dooley, Caroline Hoxby, and Enrico Moretti for helpful comments and discussions. We also thank Michael Greenstone, Richard Hornbeck, and Enrico Moretti for providing their CPS employment transitions data. Justin Hicks and Nolan Noble provided outstanding research assistance. The views expressed herein are those of the authors and do not necessarily reflect the views of TIAA-CREF or the National Bureau of Economic Research.

NBER working papers are circulated for discussion and comment purposes. They have not been peerreviewed or been subject to the review by the NBER Board of Directors that accompanies official NBER publications.

(C) 2009 by Shawn Kantor and Alexander Whalley. All rights reserved. Short sections of text, not to exceed two paragraphs, may be quoted without explicit permission provided that full credit, including (C) notice, is given to the source. 
Do Universities Generate Agglomeration Spillovers? Evidence from Endowment Value Shocks Shawn Kantor and Alexander Whalley

NBER Working Paper No. 15299

August 2009

JEL No. I2,O3,R1

\begin{abstract}
$\underline{\text { ABSTRACT }}$
In this paper we quantify the extent and magnitude of agglomeration spillovers from a formal institution whose sole mission is the creation and dissemination of knowledge -- the research university. We use the fact that universities follow a fixed endowment spending policy based on the market value of their endowments to identify the causal effect of the density of university activity on labor income in the non-education sector in large urban counties. Our instrument for university expenditures is based on the interaction between each university's initial endowment level at the start of the study period and the variation in stock market shocks over the course of the study period. We find modest but statistically significant spillover effects of university activity. The estimates indicate that a $10 \%$ increase in higher education spending increases local non-education sector labor income by about $0.5 \%$. As the implied elasticity is no larger than what previous work finds for agglomeration spillovers arising from local economic activity in general, university activity does not appear to make a place any more productive than other forms of economic activity. We do find, however, that the magnitude of the spillover is significantly larger for firms that are technologically closer to universities in terms of citing patents generated by universities in their own patents and sharing a labor market with higher education.
\end{abstract}

Shawn Kantor

School of Social Sciences, Humanities and Arts

University of California, Merced

5200 N. Lake Road

Merced, CA 95343

and NBER

skantor@ucmerced.edu

Alexander Whalley

School of Social Sciences, Humanities, Arts

University of California, Merced

5200 N. Lake Road

Merced, CA 95343

and NBER

awhalley@ucmerced.edu 


\section{Introduction}

The geographic concentration of economic activity is a salient feature of developed economies. There are a number of reasons to suspect that the positive externalities associated with the clustering of labor and capital in urban areas accounts for the dramatic economic density we observe. For example, density allows producers to access suppliers more easily and inexpensively, enables them to reach customers more efficiently, and raises the prospects of hiring high-quality workers in a thick labor market. Furthermore, the thick labor market that a city offers mutually benefits workers who can mitigate their unemployment risk and raise their own chances for a quality employer-match. ${ }^{1}$ Economists have also devoted significant attention to understanding the importance that knowledge spillovers play in contributing to the increasing returns of geographic density. ${ }^{2}$ According to Marshall (1890, 332), when productive people locate closely "The mysteries of the trade become no mysteries; but are as it were in the air . . . Good work is rightly appreciated, inventions and improvements in machinery, in processes and the general organization of the business have their merits promptly discussed; if one man starts a new idea it is taken up by others and combined with suggestions of their own; and thus becomes the source of yet more new ideas."

While Marshall seems to have emphasized the organic nature in which knowledge is transferred and is developed, in this paper we seek to measure the extent and magnitude of agglomeration spillovers from a formal institution whose sole mission is the creation and dissemination of knowledge - the research university. ${ }^{3}$ In other words, since research universities exist and are heavily subsidized to "spill knowledge," it seems natural to look here first to understand the importance of knowledge spillovers in agglomeration economies in general. ${ }^{4}$ Despite the promi-

\footnotetext{
${ }^{1}$ There is a voluminous and growing literature measuring the determinants and magnitudes of agglomeration spillovers. While not an exhaustive account of the literature, see for example Lucas (1988), Romer (1990), Krugman (1991a,b), Rauch (1993), Audretsch and Feldman (1996, 2004), Ciccone and Hall (1996), Ellison and Glaeser (1997, 1999), Black and Henderson (1999), Glaeser (1999), Glaeser and Mare (2001), Rosenthal and Strange (2001, 2003, 2004, 2008), Dumais, Ellison, and Glaeser (2002), Davis and Weinstein (2003), Henderson (2003), Duranton and Puga (2004), Moretti (2004 a,b,c), Ottaviano and Thisse (2004), Ciccone and Peri (2006), Shapiro (2006), Ellison, Glaeser, and Kerr (2007), Glaeser and Kerr (2009), and Iranzo and Peri (2009).

${ }^{2}$ For a recent review of this strand of the agglomeration literature, see Henderson (2007).

${ }^{3}$ Of course, more recently research universities have been engaged in the commercialization of their knowledge creation.

${ }^{4}$ The public subsidy to higher education in the U.S. to create and disseminate knowledge is significant. In FY 2008 public universities received $\$ 85$ billion from state and local governments for their wide-ranging activities from teaching, research, to outreach (SHEEO 2009, Table 6). The federal government, in FY 2007, contributed $\$ 30.4$ billion to the research and development activities of colleges and universities (NSF 2009). In addition,
} 
nence of high-profile university-industry partnerships in Silicon Valley and along the Route 128 corridor, there is a relatively small but growing body of empirical research that has attempted to measure the role that universities play in contributing to economic growth at the relatively local level. Following Jaffe (1989; see also Acs, Audretsch, and Feldman 1991) much of the research has explored the spillover effects of academic research on such outcomes as patents, innovations, business start-ups, or employment changes. ${ }^{5}$ While the prior research has shown the importance of academic research to the development of specific local industries, such as pharmaceuticals or electrical and electronic equipment, and that the productivity gains from academic research tend to be highly localized, we still have little understanding of the extent to which research university activities contribute to broad-based regional economic development. ${ }^{6}$

This paper seeks to address this question directly. We focus specifically on relatively large counties from 1981 to 1996 and examine how research university activity in these urban counties affected the wages that were paid to workers outside the higher education sector. The main challenge we face is that university activity does not occur randomly. For example, the research, teaching, and outreach activities of Stanford University both influences, and is influenced by, the productivity and income of firms and workers in the surrounding Silicon Valley (Santa Clara County). The endogeneity arises because the activities of universities themselves may be directly affected by the presence of highly productive and innovative firms in a region. Highly productive firms may provide the intellectual or physical capital needed for a university-industry partnership to be successful. In addition, if knowledge spillovers are present, then they are likely to flow in both directions. Universities benefit from the presence of highly productive many individuals, foundations and firms donate large sums to universities, often to enhance the performance of institutions they support or to sponsor specific research endeavors. In FY 2008 universities received $\$ 31.6$ billion in voluntary support from non-governmental sources (CAE 2009).

${ }^{5}$ See, for example, Bania, Eberts, and Fogerty (1993), Audretsch and Feldman (1996), Anselin, Varga, and Acs (1997, 2000), Zucker, Darby, and Brewer (1998), Varga (2000), Adams (2002), Cohen, Nelson, and Walsh (2002), Woodward, Figueiredo, and Guimarães (2006), Abramovsky, Harrison, and Simpson (2007), Toole (2007), Furman and MacGarvie (2007), and Andersson, Quigley, and Wilhelmsson (2009). Beeson and Montgomery (1993) took a broader approach and tested whether the quality of a university had an impact on regional employment growth rates, the percentage of the labor force employed as scientists and engineers, regional income, employment, net migration, or the share of employment in high-tech industries.

${ }^{6}$ Aghion, Boustan, Hoxby, and Vandenbussche (2009) consider the impact of research university activity on state economies in an endogenous-growth framework. Their study finds that exogenous increases in research university activity has a greater impact on economic growth in states close to the technological frontier. Part of the reason for this disproportionate benefit is that potential beneficiaries of such education migrate to the frontier states and away from the distant-frontier states. They also find that innovation, in the form of patent activity, increases as a result of the exogenous shocks to higher education. 
and innovative neighboring firms and workers, much as innovative firms do from the presence of a research university. Furthermore, the presence of highly-productive firms may increase the local demand for workers trained in a university setting who transition to local jobs - that is, graduating undergraduate and graduate students, as well as former postdoctoral researchers. Thus, naively examining the cross-sectional correlation between university activity and labor income of workers in the neighboring area may lead one to conclude that universities generate agglomeration spillovers, when in fact the causal link is unclear. Our estimation strategy seeks to isolate the spillover effects of research universities' activities on their local economies.

To address the endogeneity concern we develop a new instrumental variables strategy based on the fact that universities are legally bound to spend a fixed fraction of the market value of their endowments in each year. ${ }^{7}$ We take advantage of the facts that shocks to stock market returns occur at the national level and that the initial market values of university endowments in a county are exogenous to the future economic activity that may occur in their respective counties. ${ }^{8}$ As urban counties across the U.S. had universities with different levels of initial endowments, when interacted with stock price fluctuations the instrument will capture variation in university activity that is exogenous to changes in local income. Using this method we can estimate the casual effect of university activity on local labor income in non-education sector firms, which is the parameter of interest.

To conduct our analysis we use previously under-explored data on each institution's annual expenditures and initial endowment values, matched to annual data on county-level, industrylevel income from 1981 to $1996 .{ }^{9}$ We draw our institutional-level information on research universities from the U.S. Department of Education's Higher Education General Information Survey (HEGIS) and the Integrated Postsecondary Educational Data System (IPEDS) which provide an annual census of all colleges and universities in the U.S. Among the numerous variables that are reported in the HEGIS/IPEDS data, our specific interest lies in the institutions' overall ex-

\footnotetext{
${ }^{7} \mathrm{~A}$ similar strategy to examine the effect of university spending on university innovation is used in Whalley and Hicks (2009).

${ }^{8}$ Conceptually, our instrumental variables strategy of using exogenously-determined price changes to gain information on local exposure to an economic phenomenon is very similar to that recently used by Black, Daniel, and Sanders (2002) to estimate the effect of local economic activity on disability program participation using the coal boom and bust, and Acemoglu, Finkelstein and Notowidigdo (2009) who estimate the effect of local income on health spending using oil price shocks.

${ }^{9}$ Our choice to end the sample period in 1996 is driven by data constraints. The U.S. Department of Education has not released the 1997 to 1999 institutional-level financial data. In addition, beginning with the 2000 data, the nature of the accounting standards used to measure expenditures by universities changed, thus rendering these data non-comparable with the earlier years.
} 
penditures and initial endowment market values, the key endogenous and instrumental variables needed for this study. Our outcome variable - average labor income in non-education sectors is drawn from the U.S. Census Bureau's County Business Patterns (CBP) dataset. These data provide measures of average annual labor income in every industry in each U.S. county.

Our empirical analysis reveals that research university activity results in modest, but statistically significant, agglomeration spillovers. Our estimates indicate that a 10 percent increase in higher education spending in an urban county increases local non-education sector labor income by about 0.5 percent. We also find that these effects are persistent, as the initial response to university activity is very similar to the five-year lagged response. The magnitude of our results is notable in that they are consistent with other estimates of agglomeration spillovers from economic activity in general. Using a variety of approaches, Glaeser and Gottlieb (2009, 24-25) estimate the elasticity of the density of economic activity (city size) on local labor income to be between 0.04 and 0.13 . On the other hand, our estimates are significantly smaller than those recently estimated by Greenstone, Hornbeck and Moretti (2008) for large manufacturing plants. The similarity of our results with many previous findings and the fact that they are smaller than the localized effects of large capital-intensive manufacturing plants indicates that universities generate no more productivity gains than other sources of economic density.

While the spillover effects from universities appear rather modest, we further investigate whether closer economic links between universities and local industries magnifies the effect, as the prior research on academic research spillovers would suggest. We consider three linkage measures. ${ }^{10}$ First, we look at how frequently industry patents cite a patent issued by a university to measure industry-specific utilization of higher education knowledge. Second, we measure the degree to which each industry employs college graduates - the other primary output of local universities. Finally, we examine whether industries that pool labor markets with the higher education sector receive larger spillovers. This measure is based on workers' two-way transitions out of (into) higher education and into (out of) other industries. We find little evidence that technologically closer industries disproportionately benefitted from enhanced university activities in the short term, but such industries benefited much more at the five-year horizon. We find that the impact on labor income in industries that used university knowledge (patents) more intensively or that were more likely to share a labor market with universities was 1.5 to 2 times greater than the impact in industries that were technologically more distant from universities.

\footnotetext{
${ }^{10}$ We follow Moretti (2004b), Ellison, Glaeser, and Kerr (2007), and Greenstone, Hornbeck, and Moretti (2008) in measuring disparate spillover effects based on different measures of economic proximity to higher education.
} 


\section{Conceptual Framework}

In this section we discuss the conceptual framework that underlies our empirical analysis of the agglomeration effects of university activity on non-education local labor markets. ${ }^{11}$ Theoretically, both wages and land rents would be required to estimate the effect of the spillover effects of university activity (see Roback, 1982). However, as Moretti (2004c) and Rosenthal and Strange (2008) point out, nominal income differences across locations are sufficient to estimate the agglomeration effect on the marginal product of labor. To see why, consider an adaptation of the open-city model from Rosenthal and Strange (2008). The model is based on the concept of spatial equilibrium, where firms and workers are indifferent across locations. In the model, firms and workers make decisions about where to locate. Spatial equilibrium wages and rents are determined by two indifference conditions. First, real wages must adjust so that workers are indifferent across locations with different amenities. Second, nominal wages must adjust so that they are equal to differences in the value of the marginal product of labor across locations.

To understand the effect of the presence of university activity on equilibrium wages and land rents, consider two different locations with and without a university. Suppose that universities enhance local workers' productivity, but do not directly affect workers' utility. ${ }^{12}$ In equilibrium, when universities generate agglomeration spillovers, firms will expand until the unit cost of production is equalized across locations. As land is an immobile factor some of the productivity gains from agglomeration will be capitalized into higher land rents. In this case, the impact of agglomeration on wages is a lower bound on the productivity gains from agglomeration, holding rents constant, even though the impact of agglomeration on wages is an exact measure of the influence of agglomeration on the marginal productivity of labor.

With this framework in mind, a natural estimating equation is:

$$
\text { lnwage }_{i t}=\alpha_{1} U_{i t}+S_{i t} \alpha_{2}+A_{i t} \alpha_{3}+\text { year }_{t}+u_{i t},
$$

where lnwage $_{i t}$ is the average non-education sector income in area $i$ at time $t, U_{i t}$ is university

\footnotetext{
${ }^{11}$ Our discussion closely follows that in Rothenthal and Strange (2008) who examine evidence for human capital spillovers in nominal wages.

${ }^{12}$ Of course, it is also possible that locations with and without a university presence have different levels of amenities that workers value. Shapiro (2006) recently estimated that 60 percent of the growth rate in employment across metropolitan areas from 1940 to 1990 can be attributed to the agglomeration effects associated with the enhanced productivity of college graduates in a city. The remainder can be attributed to the notion that more highly educated areas experience more rapid growth in quality of life, which in turn contributes to growth in employment, wages, or rents.
} 
activity in area $i$ in period $t, S_{i t}$ is a vector measuring the average skill level of workers in area $i$ in period $t, A_{i t}$ is vector of attributes that affect worker utility and firm productivity in area $i$ in period $t$, and $u_{i t}$ is the error term. Our central parameter of interest is $\alpha_{1}$ which measures the responsiveness of local non-education sector nominal wages to university activity.

A central challenge in estimating the casual effect of university activity on wages, as represented in equation (1), is that many elements of $S_{i t}$ and $A_{i t}$ are unobserved. More importantly, university activity does not occur at random. University location and scale are likely to be correlated with the unobservable elements of $S_{i t}$ and $A_{i t}$. For example, universities are likely to locate and expand where the demand for skill or potential for research collaboration is greatest. If these areas also have the most productive firms, then they would pay higher wages anyway. It is also possible that university communities contain attributes that workers are likely to value, such as the presence of vibrant arts, cultural, or athletic amenities. If workers value such amenities, then, all else constant, firms would be able to offer lower wages. Furthermore, as a central output of universities is college graduates, we might expect that areas with a university would attract skill-intensive industries, and thus would have a workforce that is higher skilled than the average location. Thus, the endogenous nature of university activity is likely to bias estimates of $\alpha_{1}$ in a simple cross-sectional OLS regression.

\section{Empirical Approaches}

We implement three strategies to address the endogenous nature of university activity. Our first strategy is to restrict our analysis to counties with a research university presence, so our focus will be on how changes in the scale of university activity affects local non-education sector labor income. Therefore, our estimate of the effect of university activity will not be confounded by the inherent differences between the types of counties that have or do not have a research university presence. Our second strategy is to difference-out time-invariant characteristics of counties and industries, which addresses a wide class of potential selection problems. Any permanent differences across counties that are correlated with the scale of university activity such as university quality, the presence of Silicon Valley, or a highly skilled labor force is factored out in the differencing. Moreover, permanent differences in the location of industries, which may be correlated with university activity, are also effectively controlled. Thus, cross-sectional differences in university activity, or factors associated with universities, across counties do not contribute to the identification. Our results are identified from within-county changes in university activity over 
time. To allay further concerns that we have not effectively dealt with endogeneity, our third strategy is to adopt an instrumental variables approach.

\subsection{First Differences}

Our goal is to estimate the responsiveness of changes in labor income to changes in university expenditures in a county using a first-differences specification. We estimate the model as,

$$
\Delta Y_{i j t}=\alpha_{1} \Delta U E_{i t}+\alpha_{2} t+\alpha_{3} \Delta S M_{t-1}+\epsilon_{i j t},
$$

where $\Delta Y_{i j t}$ is the first-difference in the logarithm of average non-education sector labor income in county $i$, sector $j$, in year $t, \Delta U E_{i t}$ is the first difference in per capita total expenditures by universities in county $i$ in year $t, t$ is a linear time trend, $\Delta S M_{t-1}$ is the first-difference in the Standard and Poor's 500 Stock index in year $t-1$, and $\epsilon_{i j t}$ is the error term. We add a control for non-linear stock market trends, $\Delta S M_{t-1}$, in our baseline first-difference model to be consistent with the IV specification below. Our parameter of interest is $\alpha_{1}$.

The first-difference specification in equation (2) effectively addresses concerns that timeinvariant county and industry characteristics might bias our estimates of the true impact of university activity. However, two concerns remain. Changes in university scale do not occur randomly. Many local productivity shocks are unobservable and are likely to affect both local wages and university activity. For example, if a local firm produces an innovation that increases its productivity and also leads to an increase in the demand for collaboration on future research projects with a local university, this unobservable innovation shock would affect both the level of wages and the extent of university activity.

The second concern with equation (2) arises because there is likely to be measurement error in the level of university expenditures in a county. Estimating the model in first-differences magnifies any problems that measurement error in university expenditures poses for the estimation of the effect on labor income. If the measurement error in university activity is classical, $\alpha_{1}$ will be biased towards zero and we will underestimate the effect of university activity on local labor income. This attenuation effect may well be important, as Rosenthal and Strange (2008) demonstrate in the context of education externalities. Thus, we hope to mitigate any concerns that measurement error will bias our estimates of $\alpha_{1}$. 


\section{$3.2 \quad$ Instrumental Variables}

To address concerns that university activity might be endogenously related to unobservable determinants of wages and that university activity is measured with error, we also estimate an IV specification. Our empirical strategy attempts to identify potentially exogenous sources of variation in university expenditures in a county. We develop our instrument by taking advantage of the fact that universities were (and still are) legally constrained to use simple spending formulas based on the market value of their endowments to determine how much of their endowments were spent in a given year. This requirement allows us to instrument for overall university expenditure by exploiting differential impacts of stock price changes across counties where universities had different levels of endowments. In particular, we instrument for $\Delta U E_{i t}$ in equation (2) with the first-stage specification,

$$
\Delta U E_{i t}=\beta_{1}\left(\Delta S M_{t-1} * I E_{i}\right)+\beta_{2} t+\beta_{3} \Delta S M_{t-1}+\epsilon_{2 i t},
$$

where $\Delta U E_{i t}$ is the first-difference in per capita university expenditures in county $i$ in year $t, \Delta S M_{t-1} * I E_{i}$ is the first difference in the Standard and Poor's 500 Stock index in year $t-1\left(\Delta S M_{t-1}\right)$ interacted with the initial, per capita market value of the endowments of all universities in county $i\left(I E_{i}\right), t$ is a linear time trend, $\Delta S M_{t-1}$ is the first-difference in the Standard and Poor's 500 Stock index in year $t-1$, and $\epsilon_{2 i t}$ is the error term.

The intuition behind our identification strategy is straightforward. Universities spend a fixed fraction of the market value of their endowments in any year because of legal constraints on the spending of endowment resources held in trust. As Ehrenberg (2000 and 2009) notes, many universities follow a rule of spending 4 to 5 percent of the market value of their endowments each year. The fixed-spending rule emerged in the early 1970s as a result of efforts to maximize the long-term value of endowment portfolios and to increase their long-term effectiveness as a source of revenue. ${ }^{13}$ Prior to the publication of an influential 1969 Ford Foundation report, there was significant uncertainty about whether state and federal laws allowed universities to spend any of the capital gains realized from their endowments' appreciation. Most universities adopted a very cautious policy in response to the uncertainty and only spent the current income - rent, interest, and dividends - their endowments generated, while leaving the principal and capital gains untouched. The cautious policy, however, led universities to heavily weight their portfolios with assets, such as bonds, that paid out current-year income. Many commentators and universities became concerned that the excessive focus on bonds meant that universities

\footnotetext{
${ }^{13}$ The discussion below draws extensively from Yoder's (2004) excellent overview of university endowment management.
} 
were foregoing potential capital gains from investing in equities, which could have had significant negative consequences for long-term endowment growth.

The Ford Foundation study clarified the legal constraints on endowment spending policies. Importantly, the study argued that is was legally permissible for endowment managers to take advantage of the higher returns of equities, while at the same time generating income for current expenditures. ${ }^{14}$ The report concluded that universities could indeed spend capital gains. The report also recommended that universities follow a total-return spending policy based on a three-year moving average of their endowments' market values, regardless of whether endowment income came from capital gains or distributions.

Yoder $(2004,10)$ notes that the average spending rate for all universities in 1999 was 4.7 percent of the market value of their endowments, with the most highly endowed spent 4.1 percent and the least endowed spent 4.8 percent. To see why the 4 to 5 percent spending rule has become a standard among universities, consider that a typical endowment portfolio of 70 percent stocks and 30 percent bonds would be expected to yield an average annual return of 9 percent over the long-term. With an historic inflation rate for university costs of 4 percent, this leaves a real return of 5 percent. Thus, spending 5 percent of the market value of an endowment ensures the long-term sustainability of an endowment's real value. Universities may have different target spending rates depending on the composition of their portfolios, their investment returns, their preferences for intergenerational equity, or their desires to increase the long-term real growth rate of their endowments, but in practice there is very little variation among institutions. ${ }^{15}$

Because universities seek the long-term sustainability of their endowments, they do not arbitrarily adjust their spending rule to short-term fluctuations in economic conditions, whether unusually favorable or negative. In other words, universities reinvest excess returns in one year

\footnotetext{
${ }^{14}$ To further clarify the exact legal parameters of endowment management, a proposed Uniform Management of Institutional Funds Act (UMIFA) was presented to state legislatures in 1972 and was widely adopted.

${ }^{15}$ While differences across institutions in their target spending rates are small, differences in the rate of return they experience may well be larger. Lerner, Schoar and Wang (2008) show that the colleges and universities in the top quartile of the SAT admission distribution experienced a 1.4 percent greater return on their endowments from 1992 to 2005 than those of a median SAT institution. Much of the difference in the rates of return are explained by different portfolio allocations, with asset selection and management differences explaining a smaller portion. One change that has generated much discussion recently is the increasing allocation toward relatively new, alternative assets such as hedge funds, private equity, and venture funds. This change is quite recent and many institutions still have very small holdings in these asset classes. Lerner, Schoar and Wang (2008) note that in 1992 these types of assets accounted for only 1.1 percent of all assets, but grew to 8.1 percent in 2005 . Thus, in our sample period of 1981 to 1996, these alternative assets made up only a small portion of endowment portfolios.
} 
in order to weather below-normal returns in another. The fixed nature of the spending rule has generated substantial controversy. In the late 1990s and early 2000s, especially, the fact that university spending from endowment funds was far below the returns they were able to achieve in financial markets led to congressional hearings on the nature of the spending policies and whether the favorable tax treatment of endowment income should continue. More recently, with the collapse in endowment values due to the 2008 financial crisis, universities have faced pressure from faculty and students to increase the spending rate from the endowment to preserve the academic quality of the institution. The fact that universities have by and large held firm on their spending policy in the face of significant pressure is largely due to the legal responsibility they have to protect the principal value of gifts to their endowments. ${ }^{16}$

Since universities all generally follow a similar percentage spending rule and all have different endowment values, exogenous stock market shocks will lead to variation in the amount of endowment income each university will be able to spend in any one year. As stock market shocks and the level of the initial endowment are exogenous to trends in local economic activity across counties, this variation provides a compelling source to identify the effects of overall university expenditures on local economies.

\subsection{Potential Challenges to the Identification Strategy}

Our identifying assumption is that absent stock price changes, labor income in counties with different levels of initial university endowments would have grown at similar rates. This assumption is reasonable since both stock market prices and the level of initial endowment should not be correlated with changes in a county's level of economic activity. Of course, counties with different initial levels of university endowment may differ in other ways that could affect local labor income, such as the skill level of the population, the productivity of local firms, or the availability of valuable amenities. Any such differences that are time-invariant will be differenced out in the first-differences model. Only differential trends in income across counties driven by

\footnotetext{
${ }^{16}$ See Salem (1992). It is worth noting that while we have discussed endowments as if they were one entity, in practice each separate gift has a separate endowment account. Many endowment gifts are restricted to funding a certain chair, scholarship, or building at an institution and universities are legally bound to disburse the money of the endowment in accordance with the donor's intent. While many gifts to university endowments have strings attached, endowment disbursements are largely fungible. That is, donors typically provide gifts to support the core activities of the university, such as hiring faculty and offering student aid, so the restrictions that donors place on gifts are unlikely to substantively alter the composition of a university's expenditures. A university could always decline gifts that were inconsistent with its mission or strategic plans.
} 
unobservables that are correlated with the level of initial endowment could pose a threat to our identification strategy. While it seems reasonable that our assumption is valid, it is instructive to consider cases where it might be violated.

First, it is possible that stock market shocks affect firms differentially. For example, small firms that are more credit constrained may be more sensitive to cyclical conditions (see, e.g., Moscarini and Postel-Vinay 2009). If the location of credit constrained firms is correlated with the initial endowment of universities in a county, then our identification assumption may be threatened. We address this and other potential concerns with firms' differential exposure to stock market shocks by estimating additional models where we allow for changes in labor income in each industry to be differentially correlated with changes in stock prices. We also estimate models where we allow changes in labor income to be differentially correlated with changes in the stock market depending on initial characteristics of the county. To the extent that we can include variables that at least partially reflect differences in productivity, this specification serves as an additional check for whether differential firm exposure to stock market shocks is driving the results. The variables we interact with the stock price fluctuations are the initial housing rent and percentage of the population who were college graduates in the county in 1980 .

Second, it is possible that stock market shocks affect universities differentially. For example, the student tuition revenue that higher-quality universities receive may be more exposed to stock market fluctuations, independent of their endowment values. As higher-quality institutions are more likely to have larger endowments, this may undermine our identification strategy. ${ }^{17}$ To address this concern we estimate models where we allow changes in labor income in each county to be differentially correlated with changes in the stock market depending on the average quality of universities in the county. To measure institutional quality we use the average of the 1991 U.S. News and World Report quality rankings of the institutions within a county. ${ }^{18}$

In sum, while we cannot completely rule out the possibility that some of the effect reported below reflects time varying county-specific changes in unobserved labor productivity within a county, it appears that many sources of spurious correlation are controlled.

\footnotetext{
${ }^{17}$ It is also possible that higher-quality universities hold a different portfolio of assets in their endowments (see Lerner, Schoar, and Wang, 2008). As higher-quality institutions are more likely to hold assets that are less correlated with stock market shocks, this will weaken our first stage for this group of universities.

${ }^{18}$ As relative institutional quality is very stable over time and the 1991 issue of USNWR was the first to include all national colleges in the rankings algorithm, we treat these data as time invariant measures of quality.
} 


\subsection{Other Estimation Considerations}

Clarity about the timing of our variables is especially important given the fact that we are identifying our parameter of interest off of changes in the variables. Many universities use the previous year's market value of endowment to determine how much is spent from the endowment in the next year. To be consistent with this fact we estimate the first stage of our IV models using one lag of stock market changes interacted with the initial endowment. In addition, the county-industry labor income variable we use is reported based on March activity. To allow for university expenditure to have time to impact local wages we also lag university spending by one year. Thus, to take account of differences across the variables in the timing of reporting and behavior we implement our first difference model in (2) as,

$$
\Delta Y_{i j t}=\alpha_{1} \Delta U E_{i t-1}+\alpha_{2} t+\alpha_{3} \Delta S M_{t-2}+\epsilon_{i j t} .
$$

The first stage for the IV model above becomes,

$$
\Delta U E_{i t-1}=\beta_{1}\left(\Delta S M_{t-2} * I E_{i}\right)+\beta_{2} t+\beta_{3} \Delta S M_{t-2}+\epsilon_{2 i t},
$$

where $\Delta U E_{i t-1}$ is the first difference in per capita university expenditure in county $i$ lagged by one year, $\Delta S M_{t-2} * I E_{i}$ is the first difference of the Standard and Poor's 500 stock index lagged two years $\left(\Delta S M_{t-2}\right)$ interacted with the initial per capita endowment level in county $i\left(I E_{i}\right)$, $t$ is a linear time trend, $\Delta S M_{t-2}$ is the first difference of the Standard and Poor's stock index lagged two years, and $\epsilon_{2 i t}$ is the error term. As stock prices follow a random walk process, we do not include stock price changes that are contemporaneous with $\Delta Y_{i j t}$ as they will not impact our parameter of interest $\alpha_{1}$.

A few other estimation details are worth noting. First, we cluster the standard errors at the county level to address the fact that university expenditure is measured at the county level and the same expenditure is impacting all industries within the county (see Moulton 1986). This clustering also allows us to address the concern that changes in labor income may by serially correlated within a county-industry cell. Second, we weight all of the industry-county cells by their employment level in 1981. Our estimates, then, represent the effect of university activity on the income of the average worker, not on the average industry-county cell. Third, in measuring the scale of university activity we use total university spending from all revenue sources, ranging from tuition, state support, federal grants, to endowment income.

Fourth, we estimate alternative versions of (4) and (5) where we allow for a five-year lag in the response to changes in university activity. Differences in estimates of $\alpha_{1}$ between models 
with different response lags help us to understand whether any spillovers are persistent or only transitory. We choose to examine a five year lag in the response of labor income to a change in university activity to better capture potential migration responses to changes in university activity. As twenty percent of Americans change counties about every five years (Glaeser and Gottleib 2009, 7), the five-year lagged responses may better capture those discussed in the spatial equilibrium literature.

Finally, we probe the validity and robustness of our estimates with a number of alternative specifications. For example, as noted in the previous section, we investigate whether differences in the impact that stock market shocks had on different types of industries, universities, or counties influence our reported results.

\section{Data}

The primary data needed to implement the empirical analysis are overall university expenditures, initial endowment market value, and local labor income in the non-education sector. We obtain annual data on each university's expenditures, endowment market values, and characteristics from the U.S. Department of Education's Higher Education General Information Survey (HEGIS) and Integrated Postsecondary Education Data System (IPEDS) from 1981 to 1996. The HEGIS/IPEDS data provide a census of all four-year colleges and universities in the U.S. and reports information on revenue, expenditure, enrollment, and institutional characteristics from each institution. HEGIS was replaced with the IPEDS survey in 1984. We choose to end our analysis in 1996 because the U.S. Department of Education has unfortunately not released the institutional financial data from the 1997 to 2000 surveys. In addition, there were significant changes in the accounting methods used to report expenditure and revenue beginning with the 2000 survey, thus making it difficult to compare to the earlier data.

Our second central data source is the U.S. Census Bureau's County Business Patterns (CBP) dataset that contains information on annual labor income by industry for each county, which is the primary outcome variable we study. We also use baseline demographic information on counties from the U.S. Census Bureau's 1983 County and City Data Book (CCDB). As a measure of the quality of each institution, we use the U.S. News and World Report (USNWR) College Rankings from 1991. Lastly, our instrumental variable uses annual data on the Standard and Poor's 500 (S\&P 500) stock market index. 
We form our analysis sample by first limiting the set of institutions to the leading research colleges and universities. We define the population of research institutions as those classified as Research I, Research II, Doctoral I, or Doctoral II in the 1994 Carnegie Classification of Higher Education Institutions. This initial sample contains 235 institutions. Since we restrict our attention to counties with populations above 250,000 and exclude the District of Columbia, the resulting sample of colleges and universities is 140 institutions. We impose this geographic restriction as we are interested in estimating the effect of research-university activity in large, diversified local economies that contain the broadest representation of industries. In addition, to preserve confidentiality, the CBP data masks industry-county cells with a small number of establishments, which are more likely to occur in relatively small counties. This sample restriction results in the loss of a few prominent research universities that are located in small counties, such as Duke University. Further, we are forced to drop nine institutions have missing endowment market values in 1981 and another three institutions that do not report expenditures in at least 15 years of our 16 -year sample period. ${ }^{19}$ For 14 institutions that are missing only one year of expenditure data, we impute the missing expenditure for the missing year by inflating the institution's prior year expenditure by the national growth rate in all institutions' expenditures. The final sample consists of 128 colleges and universities located in a total of 81 counties. ${ }^{20}$

We aggregate the institution-level data to the county-level. We keep all SIC 2-digit industries in the CBP data, but drop tobacco manufacturing (2100) as it is a highly geographically concentrated industry. We also drop the education sector (SIC 8200) and agriculture, minerals and mining (SIC of less than 1500) from the analysis. As there is some entry and exit of small county-industry cells in the CBP data, likely caused by the masking of confidential information, we restrict our analysis to the industries that are reported consistently over time within a county. There are a potential 58 industries, across 81 counties, over 15 years included in the dataset, although not all industries are reported in each county.

We construct our instrument by interacting the initial (1981) endowment market value in

\footnotetext{
${ }^{19}$ In eliminating the nine universities without initial endowment data, we are forced to drop five counties from our sample because five of the institutions were the only research universities in their respective counties. The two most prominent losses include SUNY-Buffalo (Erie County, NY) and the University of Utah (Salt Lake County, UT). The four other counties are considered in our analysis, but without the influence of the university that was dropped because of the missing endowment information. As a result of dropping the three universities with missing expenditure data, we were forced to drop one county that only had the single research university (Rutgers (New Brunswick) - Middlesex County, NJ). For the other two universities, their counties remain in the sample.

${ }^{20}$ To illustrate the range of universities and counties in the sample, Appendix Table A1 shows a list of the top and bottom 10 counties in terms of initial endowments.
} 
each county with the change in the Standard \& Poor's 500 Index in each year, appropriately lagged (see equation (5)). We normalize the S\&P 500 Index so that the 1981 value is one. As university expenditure is reported for the fiscal year from July to June, we use the average value of the S\&P Index over the fiscal year so that the timing of stock market shocks line up with the timing of university expenditures.

Columns (1) and (2) of Table 1 show the means and standard deviations of various county characteristics, computed over all large counties (populations greater than 250,000) in the first year of the sample, dividing large counties by whether or not they have a university. Column (3) presents t-statistics for a test of differences in the means between columns (1) and (2). The comparison yields a number of interesting results. First, nominal labor income in noneducation industries is statistically significantly higher in research university counties than in non-university counties. Second, university counties are much larger and have higher crime rates. There is little difference in the education level of the work force, per capita income, or housing rents across the sets of counties, however. Third, there are also significant differences in the industry distribution of the workforce. University counties have less employment concentrated in retail trade, and more employment concentrated in transportation and communications, finance, insurance, real estate services, and other services. Table 1 demonstrates that the differences between university and non-university counties in non-education sector labor income could be due to a number of observable differences. As there are also likely significant differences in unobservable determinants of nominal income between university and non-university counties, our central empirical analysis focuses on university counties alone.

Table 2 presents descriptive statistics for the subsample of 81 urban (populations greater than $250,000)$ counties that have research university activity. Columns (1) and (2) show the means and standard deviations of various county characteristics, dividing the sample counties based on whether their university expenditures in 1981 fell above or below the median value. Column (3) presents t-statistics for a test of differences in the means between columns (1) and (2). The table reveals that counties with above- and below-median university expenditures do differ on a number of key observables, but the exact differences are quite different from those identified in Table 1. First, nominal labor income in non-education sectors does not differ between aboveand below-median university expenditure counties. In contrast to Table 1, this cursory look would suggest little marginal impact of university activity. Second, counties with higher levels of university expenditures have a significantly larger university sector, are more likely to have higher-quality institutions. In addition, there are significant differences between the two groups in terms of the size and average skill level of the populations. As these characteristics are likely 
to affect county wage levels independently of university spending, and likely correlated with important unobservables, this comparison demonstrates the value of using an IV strategy to achieve a causal estimate of the impact of university activity.

Table 2 also reveals that above- and below-median university activity counties differ in terms of how their labor forces are distributed across industries. Counties with above-median university expenditures have a larger fraction of the labor force in finance, insurance, real estate services than those with below-median university activity. This difference suggests, like Table 1, that the unobserved characteristics of firms are likely to differ across counties with varying levels of university activity. As the location and scale of high productivity-firms may well determine university activity, this comparison again demonstrates the value of using an IV approach.

\section{$5 \quad$ Regression Results}

\subsection{Cross-Sectional Results}

We first consider cross-sectional models of the relationship between university activity and local non-education sector labor income. In these models, we consider two different samples of counties. First, we examine the full sample of large counties to test whether counties with universities had higher levels of labor income in non-education industries. Our measure of university presence in this context is a simple dummy variable taking the value of 1 if the county had a research university, 0 otherwise. Second, we restrict our sample to those counties with a university and test whether relatively higher levels of university expenditures were associated with higher levels of non-education industry labor income.

The models we estimate can be expressed as an extended version of the model in equation $(1)$

$$
\operatorname{lnIncome}_{i j t}=\alpha_{1} U_{i t}+\alpha_{2} S_{i}+\alpha_{3} A_{i}+\alpha_{4} t+\epsilon_{i j t}
$$

where $\operatorname{lnIncome}_{i t}$ is the log of the average non-education sector income in area $i$, industry $j$, at time $t, U_{i t}$ is a variable measuring university activity in area $i$ in period $t, S_{i}$ and $A_{i}$ are matrices containing skill and amenity characteristics of county $i$, including the percentage of the population who are college graduates, the crime rate, and the percentage of service receipts received by amusement providers, $t$ is a linear time trend, and $\epsilon_{i j t}$ is the error term. The variables in $S_{i}$ and $A_{i}$ are fixed over time as they come from the 1983 County and City Data 
Book. The parameter of interest is $\alpha_{1}$, which measures the responsiveness of local labor income to university activity.

We estimate two versions of equation (6). The first version does not contain any of the controls in $S_{i}$ and $A_{i}$, while the second one does. To the extent that university activity occurs in areas where workers are likely to receive higher incomes regardless of university activity, and the observable measures capture the relevant variation, we would expect $\alpha_{1}$ to be larger in the unconditional model than in the regression-controlled model.

Table 3 displays the results from the estimation of equation (6) with the two different measures of university activity, both with and without socioeconomic controls. The results of a single regression are displayed in each column. In column (1) we can see that workers in the non-education sector in large counties with a university receive about 10 percent more labor income than those in counties without a university. In column (2) of Table 3, we show that adding observable measures of the skill level or amenities of the county reduces the estimate. With the additional controls the estimated coefficient indicates that university activity increases non-education sector labor income by about eight percent. The estimate remains statistically different from zero at the $1 \%$ level.

In columns (3) and (4) we restrict our attention to those large counties that had research university activity. While the magnitude of the coefficient in column (3) is close to the one in column (1), the coefficient is not statistically significant. Adding the location characteristics in column (4) causes the coefficient to be very close to zero and is statistically insignificant.

The results in Table 3 demonstrate that the magnitude and existence of a relationship between university activity and non-education sector labor income are sensitive to basic specification changes. The fact that we only obtain statistically significant results in the first two columns may reflect the fact that variation in spending levels across university counties - or variations with-in a county over time - may have a smaller effect on local labor income than the actual presence of a university itself. Alternatively, the results in Table 3 may indicate that the location of universities is endogenously determined by unobserved differences in productivity across areas, whereas university scale is not. The fact that adding observable measures of population skill and amenities shifts our estimate of $\alpha_{1}$ toward zero suggests that other unobserved measures are also likely to affect the precise estimate of $\alpha_{1}$. With this in mind, we turn to our first-difference and IV estimates. 


\subsection{Main Results}

We adopt the difference and IV models to address the concern that time-invariant unobservable determinants of university activity, which are also correlated with the level of labor income, could bias the estimated relationship between university activity and labor income.

First Stage. Our IV strategy exploits variation in university activity across counties arising from the fact that counties had varying levels of initial research university endowments that were all exposed to similar financial market shocks over time. In Table 4 we present the results from estimating the first-stage model in equation (5). The estimates in Table 4 show that the coefficient on the interaction between initial endowment and stock market fluctuations results in a strong first stage. The F-statistic on the excluded instruments in the first stage is well above the threshold level of 10 that has been established as key to reducing the finite sample bias inherent in IV methods (Bound, Jaeger, and Baker, 1995).

The coefficient estimate of the instrument's impact on the change in university expenditures reported in Table 4 translates into a .3 cent marginal effect. It is important to note that our first-stage estimate of $\beta_{1}$ will not yield the typical endowment spending policy of four to five percent of the marginal change in the endowment's market value. The lower coefficient estimate is likely the result of the fact that our first-stage model estimate is a different parameter than the one we would need to estimate to uncover the exact spending rule that universities follow. ${ }^{21}$ In our first stage we are using only the initial level of the endowment interacted with stock market shocks, whereas universities determine their endowment spending income based on the current year's market value. Thus, as endowment levels grow over time because of compounded returns and new donations, we will increasingly underestimate the market value of each year's

\footnotetext{
${ }^{21}$ With data on the market values of universities' endowments and expenditures in each year, we estimate a spending rule that is very close to that suggested in the text above. When we examine these data we estimate that research universities typically spend 4.4 percent of the previous year's endowment market value in a given year. To uncover the de facto spending rule we estimated the following model,

$$
\text { EndowInc }_{i t}=\gamma_{1} \text { MarketValue }_{i t-1}+\gamma_{2} t+\epsilon_{i t},
$$

where EndowInc it is university expenditure from endowment income in county $i$ in year $t$, and MarketValue $i t$ is the market value of the university endowment in county $i$ in year $t$, and $\epsilon_{i t}$ is the error term. The parameter $\gamma_{1}$ provides an estimate of the endowment spending rule. We also examine whether other additional lagged years of market value predict endowment income given the three-year-moving-average policy noted above would indicate. We find some evidence that earlier lags of endowment market value do predict spending from the endowment, but they are typically weaker than the market value in the year prior. As we are seeking to estimate our model using a just-identified strategy we do not make use of these additional, though weaker, potential exclusion restrictions.
} 
endowment and, thus, underestimate the coefficient. Further, we are estimating changes in university expenditures not only on initial endowments, but also on fluctuations in stock market returns. To the extent that universities invested in a wide portfolio of assets, not just equities, our estimate of $\beta_{1}$ will be biased toward zero. Nonetheless, despite the shortcomings in using our instrument to uncover a precise estimate of the rule that universities use when deciding how much endowment income to spend, it performs powerfully as an instrument for university expenditures.

We also report the first-stage estimates for the models that add additional interactions between the fixed characteristics of the county and stock market shocks in Appendix Table A2. Even with these additional stock market interactions, our central exclusion restriction has significant explanatory power in explaining changes in university expenditures. Also, the lowest F-statistic on the excluded instrument(s) is above 10, indicating that the additional interactions do not lead to a significant weak instrument problem.

First Differences. Table 5 reports the central results of the paper. We divide the table into two panels. The top panel presents the results for the short-run response to university activity by estimating equation (4). The bottom panel presents models where we allow a five-year lag in the response to changes in university activity. ${ }^{22}$ Again, each column presents the results from one estimation. Column (1) presents OLS estimates of the first-differences model and column (2) presents the IV estimates of the first-differences model.

In column (1) of the top panel of Table 5, the OLS estimate indicates that a one-standarddeviation increase in university activity (0.95) statistically significantly increases non-education labor income by six percent. In column (1) of the bottom panel, the estimated effect remains statistically significant at the five-year horizon, though the magnitude is about two-thirds of the short-run effect. That the effect decays indicates that little of the estimated response is due to delayed investment responses by local firms. Further, as the effect does not decay completely, the results suggest that spillovers from university activity are persistent.

Instrumental Variables. In column (2) of Table 5 we present the IV estimates. In the top

\footnotetext{
${ }^{22}$ The exact model we estimate is,

$$
\Delta Y_{i j t}=\alpha_{1} \Delta U E_{i t-6}+\alpha_{2} t+\alpha_{3} \Delta S M_{t-7}+\epsilon_{i j t},
$$

where $\Delta U E_{i t-6}$ is the first difference of per capita university expenditures in county $i$ lagged by six years, $t$ is a time trend, $\Delta S M_{t-7}$ is the first difference of the S\&P 500 stock index lagged seven years, and $\epsilon_{i j t}$ is the error term. For the IV models we also estimate (5) with similar lag structure.
} 
panel the estimate indicates that a one-standard-deviation increase in university activity (0.95) increases non-education labor income by 10 percent. This estimate is statistically significantly different from zero at the 10 percent level. In the lower panel the IV estimate of the five-year effect is approximately three-fourths the magnitude of the short-term effect and is statistically significant at the one percent level.

A few points are worth noting in comparing the estimates thus far. First, the magnitudes of the IV estimates of the difference models in Table 5 are strikingly similar to the unconditional cross-sectional estimates in Table 3 . This similarity suggests that unobservable determinants of local non-education sector labor income are not as strongly correlated with the level of university activity as we may have feared. Second, both the first-difference IV and cross-sectional estimates are larger than the first-difference OLS estimates. This finding indicates that problems with measurement error in university activity may be attenuating the first-difference results toward zero. Third, while the five-year first-difference OLS result is about two-thirds the magnitude of the one-year response, the IV results show that the five-year impact of university expenditures is more lasting.

Estimate Magnitudes. Expressing our coefficient estimates in Table 5 as elasticities helps to compare our results with others in the agglomeration literature. From our structural equation (1), a one-unit change in the level of university activity can be expressed in terms of our estimated coefficient as: $\alpha_{1} * \frac{1}{\text { countypopulation } * 1,000}$. Taking the average population of a university county from Table 1 as 985 thousand people and the estimate of $\alpha_{1}=0.083$ from column (2) of the bottom panel of Table 5, we can compute the effect of a 10 percent change in university activity on non-education sector labor income. Given that the average level of university activity in a county in the full sample is $\$ 660$ million, the implied elasticity of a 10 percent increase in this level of university activity is 0.56 percent. ${ }^{23}$ Comparing our results on the spillover from university activity with other estimates of agglomeration effects in general suggests that our implied elasticity fits within the lower end of the range that has been estimated previously. Glaeser and Gottleib (2009, 24-25) estimate that the elasticity of the density of economic activity (as measured by city size) on local labor income is 0.04 to $0.13 .^{24}$

In addition, it is useful for compare our elasticity measure to that recently estimated for million dollar plants by Greenstone, Hornbeck and Moretti (2008). They measure the impact

\footnotetext{
${ }^{23}$ That is, $\Delta U_{i t} \times \alpha_{1} \times \frac{1}{\text { countypopulation } * 1,000}=66,000,000 \times .083 \times \frac{1}{985,000 * 1,000}=.00556$

${ }^{24}$ See also Glaeser and Gottlieb (2008). Their estimates are based on replicating the methods developed by Ciccone and Hall (1996), Rosenthal and Strange (2003), and Combes, Duranton, Gobillon, and Roux (forthcoming).
} 
of opening a million dollar plant on local labor income as 2.7 percent (p. 34). On average, they estimate that a million dollar plant increases the level of economic activity in a county by 8.6 percent (p. 45). Thus, a 10 percent increase in the activity of million dollar plants results in an increase in county labor income of 3 percent. Spillovers from million dollar plants are evidently much larger than those from university activity, no doubt stemming from the fact that the production processes in higher education and manufacturing are quite different. The two principal outputs of universities - skilled labor and knowledge creation - and inputs - faculty and capital - are highly mobile factors that can migrate across markets at relatively low cost. In contrast, large manufacturing establishments often utilize inputs and produce outputs that are expensive to move across markets. As Greenstone, Hornbeck, and Moretti (2008) argue, the fact that the location decisions of million dollar plants generate bidding from local governments may indicate that they are especially likely to generate large positive spillovers to incumbent firms. Universities, on the other hand, receive financial support from higher-levels of government. In

any case, our results indicate there is little evidence that non-education spillovers from university activity are significantly larger than those of other types of economic activities that increase the density of economic activity.

\subsection{Additional Stock Market Exposure Controls}

In this section we examine whether our results are robust to allowing labor income in different industries and counties to be differentially correlated with stock market shocks. If, for example, firms that are more sensitive to cyclical conditions are located in counties with relatively high levels of initial university endowments, then our IV strategy would be weakened. To test for these possibilities we estimate various versions of the models in equations (4) and (5) where we allow the effect of stock market shocks to affect labor income through other time-invariant characteristics of industries and counties. Specifically, we extend models (4) and (5) as,

$$
\Delta Y_{i j t}=\alpha_{1} \Delta U E_{i t-1}+\alpha_{2} t+\alpha_{3} \Delta S M_{t-2}+\alpha_{4} C_{i, j}+\alpha_{5}\left(\Delta S M_{t-2} * C_{i, j}\right)+\epsilon_{i j t} .
$$

The first stage of the IV model then becomes,

$$
(10) \Delta U E_{i t-1}=\beta_{1}\left(\Delta S M_{t-2} * I E_{i}\right)+\beta_{2} t+\beta_{3} \Delta S M_{t-2}+\beta_{4} C_{i, j}+\beta_{5}\left(\Delta S M_{t-2} * C_{i, j}\right)+\epsilon_{2 i t},
$$

where $\Delta U E_{i t-1}$ is the first difference of per capita university expenditures in county $i$ lagged by one year, $\Delta S M_{t-2}$ is the first difference of the $\mathrm{S} \& \mathrm{P}$ stock index lagged two years, $C_{i, j}$ is the 
additional initial characteristic in county $i$ or industry $j$ we include, and $\epsilon_{i j t}$ and $\epsilon_{2 i t}$ are the error terms.

Measures. We consider four measures of relevant differences across industries and counties. The first measure of $C_{i, j}$ is a set of industry dummy variables. This approach allows each industry to be differentially impacted by stock market shocks. While this method does not seek to explain why labor income in some industries is more or less correlated with stock market shocks, it is very flexible. If differences across industries in the sensitivity of labor income to stock market shocks explain our results, then we would expect to observe that our estimate of $\alpha_{1}$ to be significantly altered from the one reported above when we include the additional controls.

We also consider three county-level characteristics as measures of $C_{i, j}$. We consider the average quality of the universities within the county, the average level of housing rent, and the fraction of the population that were college graduates in a county. Average university quality is measured in 1991 and the two other county characteristic variables were measured in 1980 . Each characteristic remains constant over the course of the estimation and is interacted with stock market fluctuations.

Results. The results for models with these additional stock market shock interactions are displayed in Table 6. There are a number of notable findings in the table. First, the results in Columns (1) and (2) demonstrate that the inclusion of industry-specific interactions with stock market shocks has little effect on the statistical significance of the main results, though the magnitude of the effect is somewhat smaller than in Table 5. For instance, the IV estimate of the five-year effect is 58 percent the size of the estimate in Table 5 . Thus, while allowing changes in labor income in each industry to be differentially correlated with stock market shocks does not change conclusions about the sign of the relationship, it does weaken the response somewhat.

We show the results for additional county characteristic interactions in columns (3) through (8). In columns (3) to (6) we see that allowing income in counties with different levels of college quality and housing rent levels to be differentially correlated with stock market shocks does little to alter the main results. This finding is important given the potential concern that universities and firms in research-university counties might be differentially exposed to stock market shocks, independent from the levels of university endowment in the local economies. Moreover, the magnitudes of the estimates are largely the same as their counterparts in Table 5. In columns (7) and (8) of the table, we show that allowing counties with different levels of education to be differentially correlated with stock market shocks does alter the main results on non-education 
labor income. The coefficient estimates, while still positive, are lower than those in Table 5 and all but the one-year OLS estimate are imprecisely estimated. These results could be caused by the fact that we are only examining 81 large counties with research universities, so perhaps the average skill of the population is highly correlated with university activity, thus confounding a separate measure of the universities' effects.

\section{Does Technological Distance Matter?}

In this section we seek to shed light on the mechanisms underlying the spillover effects we have identified. A number of theories of agglomeration spillovers suggest that the magnitude of the spillover effect is related to input and output linkages or the pooling of labor markets (see Moretti 2004b, Ellison, Glaeser, and Kerr 2007, and Greenstone, Hornbeck and Moretti 2008). Therefore, we test for evidence of heterogeneous responses depending on how technologically close an industry is to the higher education sector. We consider two measures of how intensively an industry uses the output of universities. First, we look at how frequently industry patents cite a patent issued by a university to measure industry-specific utilization of higher education knowledge. ${ }^{25}$ Second, we measure the intensity of each industry's employment of college graduates. The measure is based on the fraction of workers in each industry who are college graduates, as calculated from the 1980 IPUMS Census micro-date. Finally, we examine whether industries that pool labor markets with the higher education sector receive larger spillovers. This measure is based on workers' transitions out of (into) higher education and into (out of) their pooling industry counterparts. Our labor market pooling measure is constructed from CPS data on the frequency of transitions of workers between higher education and other industries. ${ }^{26}$

In Table 7 we present the results where we stratify by industry patent citation intensity. ${ }^{27}$ There is very little difference in the impact of university activity across above-median and belowmedian patent citation industries in the short term. The magnitudes of the IV estimates in the top panels of columns (2) and (4) correspond very closely with those in Table 5. The five-

\footnotetext{
${ }^{25}$ We construct our industry patent citation measure from the NBER patent database (Hall, Jaffe, and Tratjenberg, 2001). For each industry we calculate the fraction of citations to other patents that were issued to universities. For this particular measure, we consider all patents issued by universities, not just the sample of universities located in urban areas that are considered in the paper.

${ }^{26}$ We thank Enrico Moretti and Richard Hornbeck for sharing their CPS transitions data.

${ }^{27}$ As many industries do not issue patents, the sample size here is necessarily smaller than the full sample used above.
} 
year effects, however, show some differences. The IV estimates for the above-median industries reported in column (2) in the bottom panel is about 1.5 times as large as the estimate for the below-median industries in the bottom panel of column (4). This result suggests that larger, medium-term spillover effects tend to accrue in counties more heavily populated with industries that utilize university knowledge more intensively in their own innovation processes.

In Table 8 we present results where we stratify industries based on the degree of their collegegraduate employment. We find little evidence that industries that use college-educated labor receive larger spillovers. In the short-term, industries with high- and low-levels of college graduate intensity receive similar spillovers from universities. In the bottom panel of Table 8 , however, we see a stronger five-year spillover effect among industries that employ fewer college graduates. One possibility is that given that our employment of college graduates is measured before the time period of the analysis, perhaps university growth provided the necessary local talent that enabled these industries to achieve convergence with their counterparts that were already employing relatively better educated workers beforehand. On the other hand, perhaps industries that employed relatively fewer college-educated workers relied more heavily on a robust university sector for technical assistance and innovative ideas and, thus, benefited disproportionately when universities expanded. In any case, Table 8 provides little evidence that spillovers from universities accrue primarily to skill-intensive industries.

Finally, in Table 9 we present results where we stratify by the degree to which industries pool labor with the higher education sector. Increases in university activity in the short term and at five years are more likely to benefit those workers who are employed in industries that experience a robust two-way labor market relationship with higher education. There are persistent differences in the magnitudes of the estimates across the different types of industries. The industries that are more likely to pool labor with universities have more than twice the responsiveness to university activity than the low-pooling intensity industries. The finding that the five-year impact of university activity is significantly greater for the high-intensity pooling industries is difficult to explain as purely the operation of a standard labor market. To the extent that higher education competes for the same set of workers as these high-intensity pooling industries, the higher labor income spilling over into those sectors makes economic sense. An expanding higher education sector, all else constant, would bid up wages in the county in the short-term. By the five-year horizon, however, we would expect that as workers migrate across labor markets, differences in wages would converge to the spatial equilibrium and wage differences across counties would again reflect productivity differences. Thus, we view the five-year results in Table 9 as consistent with university agglomeration spillovers accruing disproportionately to industries 
that pool a labor market with universities.

\section{Conclusion}

In this paper we demonstrate that university activity does indeed generate persistent spillovers to local firms and workers. The estimated effects are quite modest, however. The estimates indicate that a 10 percent increase in university activity in a county increases local labor income in other sectors by 0.5 percent. Our estimates imply very similar elasticities to those calculated in Glaeser and Gottlieb (2008 and 2009) for local agglomeration effects from city size in general. This comparison is important in that it suggests that university activity, at least from the typical local firm's perspective, does not offer unique spillovers despite the fact that research universities focus on producing basic knowledge and innovation, and a skilled workforce. The spillovers are perhaps relatively small because such outputs are highly mobile across geographic areas. Our estimates are substantially smaller than those recently estimated by Greenstone, Hornbeck and Moretti (2008) who measured the spillovers from large manufacturing plants. Our implied elasticity of local labor income's responsiveness to university activity is less than a fifth of what they find for large manufacturing plants. One explanation is that spillovers from universities accrue to larger geographic regions, while manufacturing plants provide direct employment and offer ancillary contracting opportunities for the local area. The differences in what type of governments subsidize universities - federal and state - versus manufacturing plants - local - corroborates the findings that local spillovers from manufacturing plants tend to be larger than those from universities.

We also find evidence that the spillovers are larger for firms that are technologically close to research universities in terms of using patents generated by universities in their own patents and sharing a labor market with higher education. In our models estimating the spillover effect after five years, we found that firms in these technologically close industries enjoy a spillover that is more than 50 percent larger than that of the typical firm that is not close. Our findings tend to confirm previous research that knowledge spillovers from universities tend to be concentrated on particular local industries, such as pharmaceuticals or electronics, and are not broad based.

There are several directions for future work. First, as the results here reveal that universities have much smaller spillover effects than those estimated for large manufacturing plants, similar studies using exogenous variation in the density of economic activity in other industries 
would be worthwhile. As we learn more about the size of spillovers from different types of industries with very different production processes, we will learn more about the driving forces behind agglomeration spillovers in general. Second, we examine labor income alone, yet future work could examine establishment level data with more detailed productivity measures. This alternative dataset would allow for the estimation of the effect of university activity on total factor productivity. Understanding how industries that are closely related to higher education in terms of innovation and shared labor markets respond to the presence of nearby university activity would help to shed light on the pathways through which university activity impacts its neighbors.

The paper also introduces a new strategy to estimate the casual spillover effect that nonprofit organizations have on local economic activity. The strategy of measuring variation in nonprofit organization activity based on shocks to endowment returns could be profitably applied to estimate the economic impact of the non-profit sector more generally. For example, estimating the effect of local hospitals or arts organizations on local economies could be estimated in a similar manner as many of these non-profits also rely on endowment income to fulfill their missions. 


\section{References}

Acemoglu, Daron, Amy Finkelstein and Matthew J. Notowidigdo, "Income and Health Spending: Evidence from Oil Price Shocks," National Bureau of Economic Research working paper 14744, 2009.

Acs, Zoltan J., David B. Audretsch, and Maryann P. Feldman, "Real Effects of Academic Research: Comment," American Economic Review 82 (Mar. 1991), 363-67.

Adams, James D., "Comparative Localization of Academic and Industrial Spillovers," Journal of Economic Geography 2 (July 2002), 253-78.

Abramovsky, Laura, Rupert Harrison, and Helen Simpson, "University Research and the Location of Business R\&D," Economic Journal 117 (Mar. 2007), C114-C141.

Aghion, Philippe, Leah Boustan, Caroline Hoxby, and Jerome Vandenbussche, "The Causal Impact of Education on Economic Growth: Evidence from U.S.," working paper (2009).

Andersson, Roland, John M. Quigley, and Mats Wilhelmsson, "Urbanization, Productivity, and Innovation: Evidence from Investment in Higher Education," Journal of Urban Economics 66 (July 2009), 2-15.

Anselin, Luc, Attila Varga, and Zoltan Acs, "Local Geographic Spillovers between University Research and High Technology Innovations," Journal of Urban Economics 42 (Nov. 1997), 422-48.

Anselin, Luc, Attila Varga, and Zoltan Acs, "Geographic Spillovers and University Research: A Spatial Econometric Perspective," Growth and Change 31 (Fall 2000), 501-15.

Audretsch, David B., and Maryann P. Feldman, "R\&D Spillovers and the Geography of Innovation and Production," American Economic Review 86 (June 1996), 630-40.

Audretsch, David and Maryann Feldman "Knowledge Spillovers and the Geography of Innovation," in J. Vernon Henderson and Jacques-Francois Thisse, ed., Handbook of Urban and Regional Economics 4, (Amsterdam: North-Holland, 2004).

Bania, Neil, Randall W. Eberts, and Michael S. Fogerty, "Universities and the Startup of New Companies: Can We Generalize from Route 128 and Silicon Valley," Review of Economics and Statistics 75 (Nov. 1993), 761-66.

Beeson, Patricia, and Edward Montgomery, "The Effects of Colleges and Universities on Local Labor Markets," Review of Economics and Statistics 75 (Nov. 1993), 753-61.

Black, Dan, Kermit Daniel, and Seth Sanders, "The Impact of Economic Conditions on Participation in Disability Programs: Evidence from the Coal Boom and Bust," American Economic Review 92 (Mar. 2002), 27-50.

Black, Duncan, and Vernon Henderson, "A Theory of Urban Growth," Journal of Political Economy 107 (Apr. 1999), 252-84. 
Bound, John, David A. Jaeger, and Regina M. Baker, "Problems With Instrumental Variables Estimation When the Correlation Between the Instruments and the Endogenous Explanatory Variables Is Weak," Journal of the American Statistical Association 90 (June 1995), 443-50.

Ciccone, Antonio, and Robert E. Hall, "Productivity and the Density of Economic Activity," American Economic Review 86 (Mar. 1996), 54-70.

Ciccone, Antonio, and Giovanni Peri, "Identifying Human Capital Externalities: Theory with Applications," Review of Economic Studies 73 (Apr. 2006), 381-412.

Combes, Pierre-Philippe, Gilles Duranton, Laurent Gobillon, and Sébastien Roux, "Estimating Agglomeration Economies with History, Geology, and Worker Effects," in Edward L. Glaeser, ed., The Economics of Agglomeration (forthcoming).

Cohen, Wesley M., Richard R. Nelson, and John P. Walsh, "Links and Impacts: The Influence of Public Research on Industrial R\&D," Management Science 48 (Jan. 2002), 1-23.

Council for Aid to Education (CAE), "Contributions to Colleges and Universities Up 6.2 Percent to 31.60 Billion," February 2009, accessed at www.cae.org.

Davis, Donald R., and David E. Weinstein, "Bones, Bombs, and Break Points: The Geography of Economic Activity," American Economic Review 92 (Dec. 2002), 1269-89

Dumais, Guy, Glenn Ellison, and Edward L. Glaeser, "Geographic Concentration as a Dynamic Process," Review of Economics and Statistics 84 (May 2002), 193-204.

Duranton, Giles and Diego Puga "Micro-Foundations of Urban Agglomeration Economies, " in J. Vernon Henderson and Jacques-Franois Thisse, ed., Handbook of Urban and Regional Economics 4, (Amsterdam: North-Holland, 2004).

Ehrenberg, Ronald G., Tuition Rising: Why College Costs So Much (Cambridge, MA: Harvard University Press, 2000).

Ehrenberg, Ronald G., "Demystifying Endowments," Cornell Higher Education Research Institute working paper 118, 2009.

Ellison, Glenn and Edward L. Glaeser "Geographic Concentration in U.S. Manufacturing Industries: A Dartboard Approach," Journal of Political Economy, 105 (October 1997): 889-927.

Ellison, Glenn, and Edward L. Glaeser, "The Geographic Concentration of Industry: Does Natural Advantage Explain Agglomeration?" American Economic Review 89 (May 1999), 311-16.

Ellison, Glenn D., Edward L. Glaeser, and William R. Kerr, "What Causes Industry Agglomeration? Evidence from Coagglomeration Patterns," American Economic Review (forthcoming), National Bureau of Economic Research working paper 13068, 2007.

Furman, Jeffrey L., and Megan J. MacGarvie, "Academic Science and the Birth of Industrial Research Laboratories in the U.S. Pharmaceutical Industry," Journal of Economic Behavior $\& 3$ Organization 63 (Aug. 2007), 759-76. 
Glaeser, Edward L., "Learning in Cities," Journal of Urban Economics 46 (Sept. 1999), 254-77.

Glaeser, Edward L., and Joshua D. Gottlieb, "The Economics of Place-Making Policies," Brookings Papers on Economic Activity (Spring 2008), 155-253.

Glaeser, Edward L., and Joshua D. Gottlieb, "The Wealth of Cities: Agglomeration Economies and Spatial Equilibrium in the United States," National Bureau of Economic Research working paper 14806, 2009.

Glaeser, Edward L., and William R. Kerr, "Local Industrial Conditions and Entrepreneurship: How Much of the Spatial Distribution Can We Explain?" Journal of Economics \& Management Strategy 18 (Fall 2009), 623-63.

Glaeser, Edward L., and David C. Mare, "Cities and Skills," Journal of Labor Economics 19 (Apr. 2001), 316-42.

Greenstone, Michael, Richard Hornbeck and Enrico Moretti, "Identifying Agglomeration Spillovers: Evidence from Million Dollar Plants," National Bureau of Economic Research working paper 13833, 2008.

Hall, Bronwyn H., Adam B. Jaffe, and Manuel Trajtenberg, "The NBER Patent Citation Data File: Lessons, Insights and Methodological Tools," National Bureau of Economic Research working paper 8498, 2001.

Henderson, J. Vernon, "Marshall's Scale Economies," Journal of Urban Economics 55 (Jan. 2003), 1-28.

Henderson, J. Vernon, "Understanding Knowledge Spillovers," Regional Science and Urban Economics 37 (July 2007), 497-508.

Iranzo, Susana, and Giovanni Peri, "Schooling Externalities, Technology, and Productivity: Theory and Evidence from U.S. States," Review of Economics and Statistics 91 (May 2009), 420-31.

Krugman, Paul, Geography and Trade (Cambridge, MA: MIT Press, 1991a).

Krugman, Paul, "Increasing Returns and Economic Geography," Journal of Political Economy 99 (June 1991b), 483-99.

Jaffe, Adam B., "Real Effects of Academic Research," American Economic Review 79 (Dec. 1989), $957-70$.

Lerner, Josh, Antoinette Schoar, and Jialan Wang, "Secrets of the Academy: The Drivers of University Endowment Success," Journal of Economic Perspectives 22 (Summer 2008), 207-22.

Lucas, Robert E., Jr., "On the Mechanics of Economic Development," Journal of Monetary Economics 22 (July 1988), 3-42.

Marshall, Alfred, Principles of Economics (New York: Macmillan, 1890).

Moscarini, Giuseppe, and Fabien Postel-Vinay, "Large Employers Are More Cyclically Sensitive," National Bureau of Economic Research working paper 14740, 2009. 
Moretti, Enrico, "Estimating the External Return to Higher Education: Evidence from Cross-sectional and Longitudinal Data," Journal of Econometrics 120 (July-Aug. 2004a), 175-212.

Moretti, Enrico, "Workers' Education, Spillovers and Productivity: Evidence from Plant-Level Production Functions," American Economic Review 94 (June 2004b), 656-90.

Moretti, Enrico, "Human Capital Externalities in Cities," in J. Vernon Henderson and Jacques-Franois Thisse, ed., Handbook of Urban and Regional Economics, volume 4 (Amsterdam: North-Holland, 2004c), 2243-91.

Moulton, Brent R., "Random Group Effects and the Precision of Regression Estimates," Journal of Econometrics 32 (Aug. 1986), 385-97.

National Science Foundation (NSF), "Academic Research and Development Expenditures: Fiscal Year 2007," Report 09-303, March 2009, accessed at http://www.nsf.gov/statistics/nsf09303/pdf/nsf09303.pdf.

Ottaviano, Gianmarco and Jacques-Franois Thisse "Agglomeration and Economic Geography," in J. Vernon Henderson and Jacques-Franois Thisse, ed., Handbook of Urban and Regional Economics 4, (Amsterdam: North-Holland, 2004).

Rauch, James E., "Productivity Gains from Geographic Concentration of Human Capital: Evidence from the Cities," Journal of Urban Economics 34 (Nov. 1993), 380-400.

Roback, Jennifer, "Wages, Rents, and the Quality of Life," Journal of Political Economy 90 (Dec. 1982), $1257-78$.

Romer, Paul M., "Endogenous Technical Change," Journal of Political Economy 98 (Oct. 1990), S71S102.

Rosenthal, Stuart S., and William C. Strange, "The Determinants of Agglomeration," Journal of Urban Economics 50 (Sept. 2001): 191-229.

Rosenthal, Stuart S., and William C. Strange, "Geography, Industrial Organization, and Agglomeration," Review of Economics and Statistics 85 (May 2003), 377-93.

Rosenthal, Stuart S., and William C. Strange, "Evidence on the Nature and Sources of Agglomeration," in J. Vernon Henderson and Jacques-Franois Thisse, eds., Handbook of Urban and Regional Economics, vol. 4 (Amsterdam: North-Holland, 2004), 2119-171.

Rosenthal, Stuart S., and William C. Strange, "The Attenuation of Human Capital Spillovers," Journal of Urban Economics 64 (Sept. 2008), 373-89.

Salem, David, "Endowment Management," in Deirdre McDonald Greene, College and University Business Administration, fifth edition (Washington, DC: National Association of College and University Business Officers, 1992).

Shapiro, Jesse M., "Smart Cities: Quality of Life, Productivity, and the Growth Effects of Human Capital," Review of Economics and Statistics 88 (May 2006), 324-35. 
State Higher Education Executive Officers (SHEEO), State Higher Education Finance Early Release FY 2008, accessed at http://www.sheeo.org/finance/shef/SHEF\%20FY08\%20Early\%20Release\%202.pdf, 2009

Toole, Andrew A., "Does Public Scientific Research Complement Private Investment in Research and Development in the Pharmaceutical Industry?" Journal of Law and Economics 50 (Feb. 2007), 81-104.

U.S. Census Bureau, County Business Patterns (CBP), 1981-1996.

U.S. Census Bureau, County and City Data Book (CCDB), 1983.

U.S. Department of Education, Higher Education General Information Survey (HEGIS) and the Integrated Postsecondary Educational Data System (IPEDS), 1981-1996.

U.S. News and World Report, "America's Best Colleges 1991," 1990.

Varga, Attila, "Local Academic Knowledge Transfers and the Concentration of Economic Activity," Journal of Regional Science 40 (May 2000), 289-309.

Whalley, Alexander, and Justin Hicks, "Estimating the Effect of Research Spending on Knowledge Production in Universities," University of California, Merced working paper, 2009.

Woodward, Douglas, Octávio Figueiredo, and Paulo Guimarães, "Beyond Silicon Valley: University R\&D and High-Technology Location," Journal of Urban Economics 60 (July 2006), 15-32.

Yoder, Jay A., Endowment Management: A Practical Guide (Washington, DC: Association of Governing Boards of Universities and Colleges, 2004).

Zucker, Lynne G., Michael R. Darby, and Marilynn B. Brewer, "Intellectual Human Capital and the Birth of U.S. Biotechnology Enterprises," American Economic Review 88 (March 1998), 290-306. 
TABLE 1: Baseline County Characteristics - University and Non-University Locations

(1) Outcome:

Average Annual Labor Income in Non-Education Sector (1981)

(2) University Characteristics:

University Expenditure

(per '000 population; 1981)

University Endowment Market Value

(per '000 population; 1981)

Fraction Public (1981)

Average Quality Ranking (1991)

$\begin{gathered}\text { University } \\ \text { Counties } \\ (1)\end{gathered}$

$\$ 16,225$
$(\$ 1,455)$

$\$ 0.67$
$(\$ 0.95)$
$\$ 0.16$
$(\$ 0.39)$
0.59
$(0.44)$
2.28
$(1.10)$

(3) Economic and Demographic Characteristics (1980):

Population

Per Capita Income (1980 \$)

$\%$ College Graduate

$\%$ Black

Average Rent

Crime Rate (Per '000 Population)

$\%$ Service Spending on Amusements

(4) Industry Distribution of Labor Force (1980; \%):

Construction

Manufacturing

Transportation and Communications

Wholesale Trade

Retail Trade

Finance, Insurance, and Real Estate

Services

Number of Counties

985,591
$(1,029,325)$
$\$ 11,521$
$(\$ 1,526)$
16

(4)

16

(14)

$\$ 255$

(\$35)

7,292

$(2,489)$

11

(18)

0.06

(0.02)

0.23

(0.08)

0.07

(0.03)

0.07

(0.02)

0.20

(0.04)

0.08

(0.03)

0.27

(0.04)
81
Non-University

Counties

(2)

$\$ 15,554$

$(\$ 1,453)$

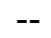

445,942

$(185,484)$

$\$ 11,200$

$(\$ 1,969)$

15

(5)

9

(9)

$\$ 258$

$(\$ 40)$

5,989

$(1,897)$

9

(12)

0.06

(0.04)

0.26

(0.11)

0.06

(0.02)

0.07

(0.03)

0.23

$(0.05)$

0.07

(0.02)

0.25

(0.06)
(1) - (2)

t-stat

(3)

3.07
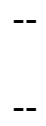

$-$

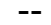

4.84

1.20

1.17

4.25

$-0.54$

3.97

1.15

$-0.53$

$-1.31$

2.47

0.86

$-3.45$

3.24

2.56 98 
Notes and Sources: Labor income data are from U.S. Census Bureau County Business Patterns; data relating to university expenditures, endowments, and ownership status are from the U.S. Department of Education Higher Education General Information Survey (HEGIS) and the Integrated Postsecondary Educational Data System (IPEDS); and college and university quality data are from U.S. News \& World Report (1991). Socioeconomic county characteristics are from the U.S. Census Bureau County and City Data Book (1983) and industrial distribution of the labor force are from U.S. Census Bureau County Business Patterns. The sample contains one observation for each county. The main entries in columns (1) and (2) are the means of the selected variable. The entries in parentheses in columns (1) and (2) are the standard deviation of the selected variables. Reported t-statistics are obtained from a regression of university county indicator on the selected variable. All reported monetary amounts are in nominal dollars. 
TABLE 2: Baseline County Characteristics for University Counties, by University Expenditure Level

\begin{tabular}{|c|c|c|c|}
\hline & $\begin{array}{c}\text { Above Median } \\
\text { University } \\
\text { Expenditure } \\
\text { Per Capita } \\
(1)\end{array}$ & $\begin{array}{c}\text { Below Median } \\
\text { University } \\
\text { Expenditure } \\
\text { Per Capita } \\
\text { (2) }\end{array}$ & $\begin{array}{c}(1)-(2) \\
\text { t-stat } \\
(3)\end{array}$ \\
\hline \multicolumn{4}{|l|}{ (1) Outcome: } \\
\hline $\begin{array}{l}\text { Average Annual Labor Income } \\
\text { in Non-Education Sector } \\
\text { (2) University Characteristics: }\end{array}$ & $\begin{array}{l}\$ 16,290 \\
(\$ 1,406)\end{array}$ & $\begin{array}{l}\$ 16,158 \\
(\$ 1,519)\end{array}$ & 0.40 \\
\hline $\begin{array}{l}\text { University Expenditure } \\
\text { (per '000 population) }\end{array}$ & $\begin{array}{l}\$ 1.13 \\
(\$ 1.16)\end{array}$ & $\begin{array}{c}\$ 0.20 \\
(\$ 0.10)\end{array}$ & 5.07 \\
\hline $\begin{array}{l}\text { University Endowment Market Value } \\
\text { (per ' } 000 \text { population) }\end{array}$ & $\begin{array}{l}\$ 0.29 \\
(\$ 0.51)\end{array}$ & $\begin{array}{l}\$ 0.03 \\
(\$ 0.04)\end{array}$ & 3.14 \\
\hline Fraction Public & $\begin{array}{c}0.64 \\
(0.43)\end{array}$ & $\begin{array}{c}0.54 \\
(0.44)\end{array}$ & 1.01 \\
\hline Average Quality Ranking & $\begin{array}{c}2.77 \\
(0.99)\end{array}$ & $\begin{array}{l}1.78 \\
(0.98)\end{array}$ & 4.54 \\
\hline \multicolumn{4}{|c|}{ (3) Economic and Demographic Characteristics (1980): } \\
\hline Population & $\begin{array}{c}701,658 \\
(427,275)\end{array}$ & $\begin{array}{c}1,221,947 \\
(1,358,519)\end{array}$ & -2.34 \\
\hline Per Capita Income (1980 \$) & $\begin{array}{l}\$ 11,613 \\
(\$ 1,549)\end{array}$ & $\begin{array}{l}\$ 11,428 \\
(\$ 1,516)\end{array}$ & 0.54 \\
\hline$\%$ College Graduate & $\begin{array}{l}17 \\
(4)\end{array}$ & $\begin{array}{l}14 \\
(3)\end{array}$ & 3.84 \\
\hline$\%$ Black & $\begin{array}{c}19 \\
(15)\end{array}$ & $\begin{array}{c}14 \\
(11)\end{array}$ & 1.59 \\
\hline Average Rent & $\begin{array}{l}\$ 251 \\
(\$ 32)\end{array}$ & $\begin{array}{l}\$ 258 \\
(\$ 38)\end{array}$ & -0.94 \\
\hline Crime Rate (Per '000 Population) & $\begin{array}{c}7,391 \\
(2,432)\end{array}$ & $\begin{array}{c}7,191 \\
(2,574)\end{array}$ & 0.36 \\
\hline$\%$ Service Spending on Amusements & $\begin{array}{c}13 \\
(24)\end{array}$ & $\begin{array}{c}9 \\
(8)\end{array}$ & 0.87 \\
\hline \multicolumn{4}{|c|}{ (4) Industry Distribution of Labor Force (1980; \%): } \\
\hline Construction & $\begin{array}{c}0.06 \\
(0.03)\end{array}$ & $\begin{array}{c}0.05 \\
(0.02)\end{array}$ & 0.76 \\
\hline Manufacturing & $\begin{array}{c}0.23 \\
(0.09)\end{array}$ & $\begin{array}{c}0.24 \\
(0.07)\end{array}$ & -0.60 \\
\hline Transportation and Communications & $\begin{array}{c}0.07 \\
(0.02)\end{array}$ & $\begin{array}{c}0.07 \\
(0.03)\end{array}$ & -0.55 \\
\hline Wholesale Trade & $\begin{array}{c}0.07 \\
(0.02)\end{array}$ & $\begin{array}{c}0.08 \\
(0.02)\end{array}$ & -0.74 \\
\hline Retail Trade & $\begin{array}{c}0.20 \\
(0.04)\end{array}$ & $\begin{array}{c}0.21 \\
(0.04)\end{array}$ & -0.95 \\
\hline Finance, Insurance, and Real Estate & $\begin{array}{c}0.09 \\
(0.04)\end{array}$ & $\begin{array}{c}0.07 \\
(0.02)\end{array}$ & 2.41 \\
\hline Services & $\begin{array}{c}0.28 \\
(0.05)\end{array}$ & $\begin{array}{c}0.27 \\
(0.04)\end{array}$ & 1.09 \\
\hline Number of Counties & 41 & 40 & \\
\hline
\end{tabular}


Notes and Sources: See Table 1. The sample contains one observation for each county. The main entries in columns (1) and (2) are the mean of the selected variable. The entries in parentheses in columns (1) and (2) are the standard deviation of the selected variables. Reported t-statistics are obtained from a regression of the selected variable on an indicator variable for counties in the above-median-university-expenditure category. All reported monetary amounts are in nominal dollars. 
TABLE 3: University Activity and Local Labor Income: Cross-Sectional Estimates, 19811996

Dependent Variable $=\log ($ Annual Labor Income in Non-Education Sector $)$

\begin{tabular}{|c|c|c|c|c|}
\hline & $(1)$ & (2) & (3) & $(4)$ \\
\hline University County dummy variable & $\begin{array}{c}0.105 * * * \\
(0.032)\end{array}$ & $\begin{array}{c}0.078 * * * \\
(0.021)\end{array}$ & -- & -- \\
\hline University Expenditure Per Capita & -- & -- & $\begin{array}{c}0.080 \\
(0.061)\end{array}$ & $\begin{array}{c}0.001 \\
(0.018)\end{array}$ \\
\hline Location Controls & No & Yes & No & Yes \\
\hline Number of Observations & \multicolumn{2}{|c|}{120,766} & \multicolumn{2}{|c|}{41,782} \\
\hline
\end{tabular}

Notes and Sources: See Table 1. The estimates presented are for alternative versions of model (6). The unit of observation is at the county-industry-year level. The sample for columns (1) and (2) is all urban counties with populations greater than 250,000. The sample for columns (3) and (4) is restricted to those counties with a research university, as defined in the text. The models in columns (2) and (4) also control for percentage college graduate, crime rate, and the percentage of service receipts received by amusement providers at the county level. All estimates are weighted by the level of employment in the industry-county cell in 1981. The entries in parentheses in columns (1)-(4) are the standard errors of the respective coefficients clustered at the county level.

* indicates significantly different from zero at the $10 \%$ level of significance;

** indicates significantly different from zero at the $5 \%$ level of significance;

*** indicates significantly different from zero at $1 \%$ level of significance. 


\section{TABLE 4: The Effect of Stock Market Shocks Interacted with the Value of Initial Endowments on University Expenditures, 1981-1996}

Dependent Variable $=\Delta$ University Expenditure Per Capita (period $\mathrm{t})$

(1)

$\Delta$ Stock Index (t-1) $\mathrm{x}$

Initial Market Value of Endowment

$\Delta$ Stock Index $(\mathrm{t}-1)$

F-Statistic:

$\Delta$ Stock Index $(\mathrm{t}-1) \mathrm{x}$

Initial Market Value of Endowment

Number of Observations
$0.0031 * * *$

$(0.0008)$

$-0.0393$

$(0.0191)$

13.77

[0.0004]

41,782

Notes and Source: See Table 1. The stock market index is the Standard \& Poor's 500 Stock Index. The estimates presented are for model (5) in the text. The unit of observation is at the county-industry-year level. $\Delta$ University Expenditure $(\mathrm{t}-\mathrm{x})$ is measured as the spending rate per ' 000 county population. Initial Market Value of Endowment is measured as the portfolio value per ' 000 county population. All estimates are weighted by the level of employment in the industry-county cell in 1981. The entries in parentheses in column (1) are the standard errors of the coefficient estimates clustered at the county level. The entries in the third row report the FStatistic for the test of whether the excluded instrument is zero. The test statistic value is reported in the main entry and the p-value of test is reported in square brackets.

* indicates significantly different from zero at the $10 \%$ level of significance;

** indicates significantly different from zero at the $5 \%$ level of significance;

*** indicates significantly different from zero at $1 \%$ level of significance. 


\section{TABLE 5: The Effect of University Activity on Local Labor Income, 1981-1996}

Dependent Variable $=\Delta \log ($ Annual Labor Income in Non-Education Sector $($ period $\mathrm{t}))$

\section{OLS}

(1)

Model I: Initial Effect

$\Delta$ University Expenditure Per Capita (t-1)

$\Delta$ Stock Index (t-2)

$$
\begin{gathered}
0.065 * * * \\
(0.022) \\
-0.039 * * *
\end{gathered}
$$

$(0.004)$

F-Statistic: $\Delta$ Stock Index $(\mathrm{t}-2) \mathrm{x}$

Initial Market Value of Endowment

Number of Observations
TSLS

(2)

\author{
$0.108 *$ \\ $(0.055)$ \\ $-0.039 * * *$ \\ (0.004)
}

13.77

[0.0004]

41,782

\section{Model 2: Five Year Effect}
$\Delta$ University Expenditure Per Capita (t-6)
$0.042 * *$
$0.083 * * *$
$\Delta$ Stock Index $(\mathrm{t}-7)$
$0.088^{* * *}$
$(0.034)$
$0.088 * * *$
$(0.005)$
(0.005)

F-Statistic: $\Delta$ Stock Index (t-7) $\mathrm{x}$

13.96

Initial Market Value of Endowment

[0.0003]

Number of Observations

28,926

Notes and Sources: See Table 1. The estimates presented are for model (4) in the text. The unit of observation is at the county-industry-year level and the sample includes all large university counties. $\Delta$ University Expenditure $(\mathrm{t}-\mathrm{x})$ is measured as spending rate per ' 000 county population. The main entries in columns (1) and (2) are coefficient estimates. All estimates are weighted by the level of employment in the industry-county cell in 1981 . The entries in parentheses in columns (1) and (2) are the standard errors of the coefficient estimates clustered at the county level. The entries in the third row and sixth row report the F-Statistic for the test of whether the excluded instrument is zero. The test statistic value is reported as the main entry, and the p-value of test is reported in square brackets.

* indicates significantly different from zero at the $10 \%$ level of significance;

** indicates significantly different from zero at the $5 \%$ level of significance;

$* * *$ indicates significantly different from zero at $1 \%$ level of significance. 


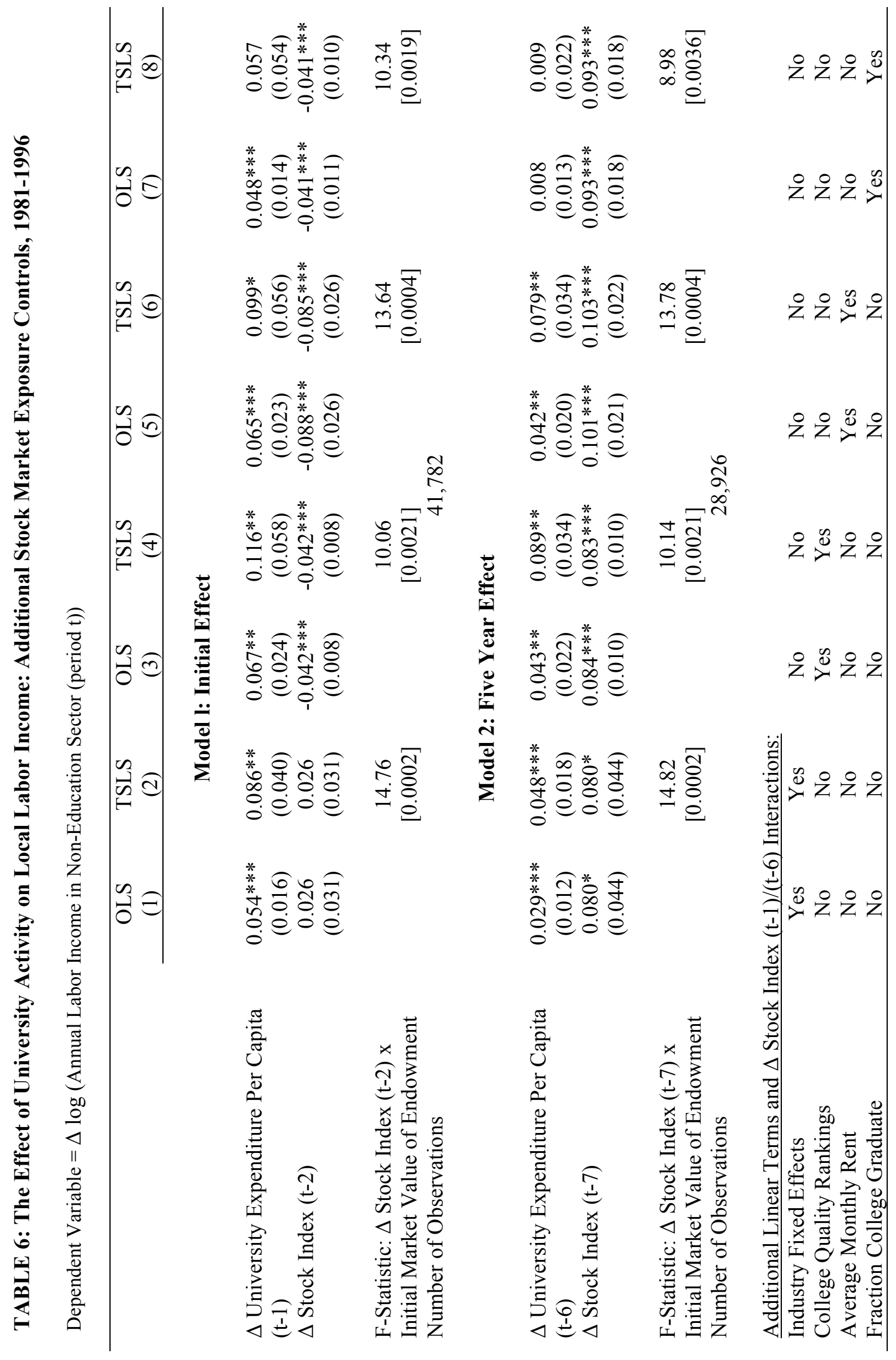




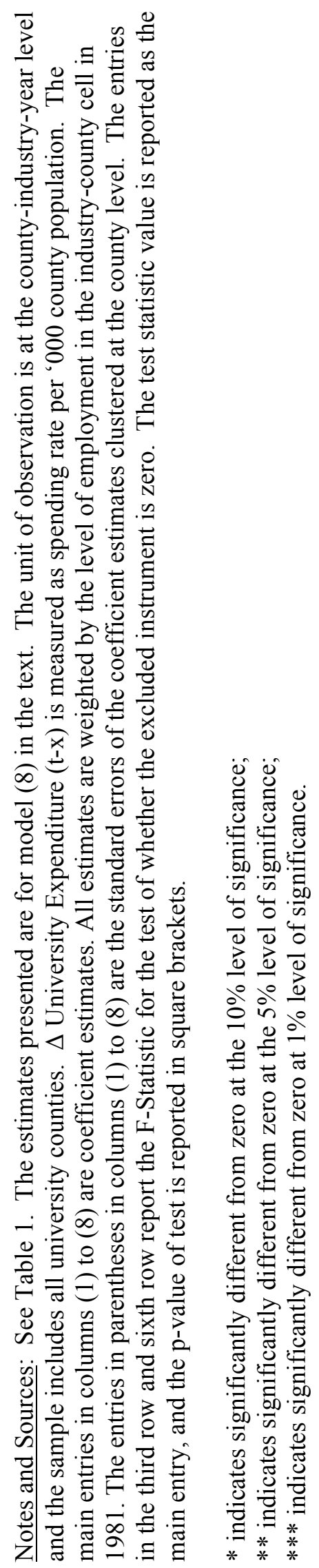


TABLE 7: The Effect of University Activity on Local Labor Income: By the Intensity of Industry's Patent Citations of University Patents, 1981-1996

Dependent Variable $=\Delta \log ($ Annual Labor Income in Non-Education Sector $($ period $\mathrm{t}))$

\begin{tabular}{|c|c|c|c|c|}
\hline \multirow{2}{*}{$\begin{array}{l}\text { Industry University Patent Citation } \\
\text { Intensity: }\end{array}$} & \multicolumn{2}{|c|}{ Above Median Intensity } & \multicolumn{2}{|c|}{ Below Median Intensity } \\
\hline & $\begin{array}{l}\text { OLS } \\
(1)\end{array}$ & $\begin{array}{l}\text { TSLS } \\
(2)\end{array}$ & $\begin{array}{l}\text { OLS } \\
(3)\end{array}$ & $\begin{array}{c}\text { TSLS } \\
(4)\end{array}$ \\
\hline \multicolumn{5}{|c|}{ Model I: Initial Effect } \\
\hline $\begin{array}{l}\Delta \text { University Expenditure Per } \\
\text { Capita }(\mathrm{t}-1)\end{array}$ & $\begin{array}{c}0.050 * * * \\
(0.017)\end{array}$ & $\begin{array}{l}0.092 * \\
(0.047)\end{array}$ & $\begin{array}{c}0.045^{* * *} \\
(0.013)\end{array}$ & $\begin{array}{c}0.093 * * \\
(0.034)\end{array}$ \\
\hline$\Delta$ Stock Index $(\mathrm{t}-2)$ & $\begin{array}{c}-0.049 * * * \\
(0.005)\end{array}$ & $\begin{array}{c}-0.049 * * * \\
(0.005)\end{array}$ & $\begin{array}{c}-0.032 * * * \\
(0.007)\end{array}$ & $\begin{array}{c}-0.032 * * * \\
(0.007)\end{array}$ \\
\hline $\begin{array}{l}\text { F-Statistic: } \Delta \text { Stock Index }(\mathrm{t}-2) \mathrm{x} \\
\text { Initial Market Value of Endowment }\end{array}$ & & $\begin{array}{c}17.56 \\
{[0.0001]}\end{array}$ & & $\begin{array}{c}22.71 \\
{[0.0000]}\end{array}$ \\
\hline Number of Observations & \multicolumn{2}{|c|}{8,853} & \multicolumn{2}{|c|}{9,100} \\
\hline
\end{tabular}

Model 2: Five Year Effect

\begin{tabular}{|c|c|c|c|c|}
\hline $\begin{array}{l}\Delta \text { University Expenditure Per } \\
\text { Capita (t-6) }\end{array}$ & $\begin{array}{c}0.017 \\
(0.014)\end{array}$ & $\begin{array}{l}0.100^{*} \\
(0.053)\end{array}$ & $\begin{array}{c}0.029 \\
(0.019)\end{array}$ & $\begin{array}{c}0.067 * * * \\
(0.021)\end{array}$ \\
\hline$\Delta$ Stock Index (t-7) & $\begin{array}{c}0.092 * * * \\
(0.008)\end{array}$ & $\begin{array}{c}0.092 * * * \\
(0.008)\end{array}$ & $\begin{array}{c}0.090^{* * *} \\
(0.009)\end{array}$ & $\begin{array}{c}0.090^{* * *} \\
(0.009)\end{array}$ \\
\hline $\begin{array}{l}\text { F-Statistic: } \Delta \text { Stock Index }(\mathrm{t}-7) \mathrm{x} \\
\text { Initial Market Value of Endowment }\end{array}$ & & $\begin{array}{c}16.92 \\
{[0.0001]}\end{array}$ & & $\begin{array}{c}18.27 \\
{[0.0001]}\end{array}$ \\
\hline Number of Observations & \multicolumn{2}{|c|}{6,129} & \multicolumn{2}{|c|}{6,300} \\
\hline
\end{tabular}

Notes and Sources: See Table 1. The estimates presented are for model (4) in the text. The unit of observation is at the county-industry-year level. The sample for the entries in columns (1) and (2) includes above-median university patent citation industries in all university counties. The sample for the entries in columns (3) and (4) includes below-median university patent citation industries in all university counties. $\Delta$ University Expenditure $(\mathrm{t}-\mathrm{x})$ is measured as spending rate per ' 000 county population. All estimates are weighted by the level of employment in the industry-county cell in 1981. The main entries in columns (1) to (4) are coefficient estimates. The entries in parentheses in columns (1) to (4) are the standard errors of the coefficient estimates clustered at the county level. The entries in the third row and sixth row report the F-Statistic for the test of whether the excluded instrument is zero. The test statistic value is reported as the main entry, and the p-value of test is reported in square brackets.

* indicates significantly different from zero at the $10 \%$ level of significance;

** indicates significantly different from zero at the $5 \%$ level of significance;

$* * *$ indicates significantly different from zero at $1 \%$ level of significance. 


\section{TABLE 8: The Effect of University Activity on Local Labor Income: By Industry Educational Attainment, 1981-1996}

Dependent Variable $=\Delta \log ($ Annual Labor Income in Non-Education Sector $($ period $\mathrm{t}))$

\begin{tabular}{|c|c|c|c|c|}
\hline \multirow[t]{2}{*}{ Industry Fraction College Graduate: } & \multicolumn{2}{|c|}{ High } & \multicolumn{2}{|c|}{ Low } \\
\hline & $\begin{array}{l}\text { OLS } \\
(1)\end{array}$ & $\begin{array}{l}\text { TSLS } \\
(2)\end{array}$ & $\begin{array}{l}\text { OLS } \\
(3)\end{array}$ & $\begin{array}{c}\text { TSLS } \\
(4)\end{array}$ \\
\hline \multicolumn{5}{|c|}{ Model l: Initial Effect } \\
\hline $\begin{array}{l}\Delta \text { University Expenditure Per } \\
\text { Capita (t-1) }\end{array}$ & $\begin{array}{c}0.068 * * \\
(0.019)\end{array}$ & $\begin{array}{l}0.092 * * \\
(0.041)\end{array}$ & $\begin{array}{l}0.059 * * \\
(0.025)\end{array}$ & $\begin{array}{l}0.112^{*} \\
(0.051)\end{array}$ \\
\hline$\Delta$ Stock Index $(\mathrm{t}-2)$ & $\begin{array}{l}-0.021^{* * *} \\
(0.004)\end{array}$ & $\begin{array}{l}-0.021 * * * \\
(0.004)\end{array}$ & $\begin{array}{l}-0.056^{* * *} \\
(0.005)\end{array}$ & $\begin{array}{c}-0.056^{* *} \\
(0.005)\end{array}$ \\
\hline $\begin{array}{l}\text { F-Statistic: } \Delta \text { Stock Index }(\mathrm{t}-2) \mathrm{x} \\
\text { Initial Market Value of Endowment }\end{array}$ & & $\begin{array}{c}15.31 \\
{[0.0002]}\end{array}$ & & $\begin{array}{c}13.08 \\
{[0.0005]}\end{array}$ \\
\hline Number of Observations & \multicolumn{2}{|c|}{21,580} & \multicolumn{2}{|c|}{18,213} \\
\hline
\end{tabular}

Model 2: Five Year Effect

$\Delta$ University Expenditure Per
Capita (t-6)

$\Delta$ Stock Index (t-7)

F-Statistic: $\Delta$ Stock Index (t-7) $\mathrm{x}$

Initial Market Value of Endowment

$\begin{array}{cccc}0.035 * * & 0.046 & 0.046^{* *} & 0.132 * * * \\ (0.019) & (0.045) & (0.017) & (0.032) \\ & & & \\ 0.076^{* * *} & 0.076^{* * *} & 0.101 * * * & 0.101 * * * \\ (0.005) & (0.005) & (0.005) & (0.005)\end{array}$

15.96

[0.0001]
13.12

[0.0005]

Number of Observations

Notes and Sources: See Table 1. The estimates presented are for model (4) in the text. The unit of observation is at the county-industry-year level. The sample for the entries in columns (1) and (2) is for above-median fraction college graduate industries in all university counties. The sample for the entries in columns (3) and (4) is for below-median fraction college graduate industries in all university counties. $\Delta$ University Expenditure $(\mathrm{t}-\mathrm{x})$ is measured as spending rate per ' 000 county population. The main entries in columns (1) to (4) are coefficient estimates. All estimates are weighted by the level of employment in the industry-county cell in 1981 . The entries in parentheses in columns (1) to (4) are the standard errors of the coefficient estimates clustered at the county level. The entries in the third row and sixth row report the F-Statistic for the test of whether the excluded instrument is zero. The test statistic value is reported as the main entry, and the $\mathrm{p}$-value of test is reported in square brackets.

* indicates significantly different from zero at the $10 \%$ level of significance;

** indicates significantly different from zero at the $5 \%$ level of significance;

*** indicates significantly different from zero at $1 \%$ level of significance. 
TABLE 9 : The Effect of University Activity on Local Labor Income: By Industry Based on Labor Market Pooling With Education Sector, 1981-1996

Dependent Variable $=\Delta \log ($ Annual Labor Income in Non-Education Sector $($ period $\mathrm{t}))$

\begin{tabular}{lcccc}
\hline Industry Fraction Labor Market & \multicolumn{3}{c}{ High } & \multicolumn{3}{c}{ Low } \\
Pooling With Education: & OLS & TSLS & OLS & TSLS \\
\cline { 2 - 5 } & $(1)$ & $(2)$ & $(3)$ & $(4)$ \\
\hline
\end{tabular}

Model I: Initial Effect

$\Delta$ University Expenditure Per

Capita (t-1)

$\Delta$ Stock Index (t-2)

F-Statistic: $\Delta$ Stock Index (t-2) $\mathrm{x}$

Initial Market Value of Endowment

Number of Observations
$0.074 * *$
(0.025)
$0.104 *$
$(0.062)$
$0.035 * * *$
$(0.011)$
$0.079 * * *$
(0.027)
$-0.045^{* * *}$
$-0.045 * * *$
$(0.005)$
$-0.034 * * *$
$-0.034 * * *$
$(0.004)$
(0.004)

10.65

26.27

[0.0016]

[0.0000]

23,478

15,792

\section{Model 2: Five Year Effect}

\begin{abstract}
$\Delta$ University Expenditure Per
Capita (t-6)
\end{abstract}

$\Delta$ Stock Index (t-7)

F-Statistic: $\Delta$ Stock Index (t-7) $\mathrm{x}$

Initial Market Value of Endowment

$\begin{array}{cccc}0.044 * * & 0.086^{* *} & 0.017 & 0.036^{*} \\ (0.022) & (0.035) & (0.014) & (0.019) \\ & & & \\ 0.091 * * * & 0.091 * * * & 0.086^{* * *} & 0.086^{* * *} \\ (0.005) & (0.005) & (0.009) & (0.009)\end{array}$

10.77

26.83

[0.0015]

Number of Observations

16,254

10,926

Notes and Sources: See Table 1. The estimates presented are for model (4) in the text. The unit of observation is at the county-industry-year level. The sample for the entries in columns (1) and (2) is for above-median education sector labor market transition industries in all university counties. The sample for the entries in columns (3) and (4) is for below-median education sector labor market transition industries in all university counties. $\Delta$ University Expenditure (t-x) is measured as spending rate per ' 000 county population. The main entries in columns (1) to (4) are coefficient estimates. All estimates are weighted by the level of employment in the industrycounty cell in 1981. The entries in parentheses in columns (1) to (4) are the standard errors of the coefficient estimates clustered at the county level. The entries in the third row and sixth row report the F-Statistic for the test of whether the excluded instrument is zero. The test statistic value is reported as the main entry, and the p-value of test is reported in square brackets.

* indicates significantly different from zero at the $10 \%$ level of significance;

** indicates significantly different from zero at the 5\% level of significance;

$* * *$ indicates significantly different from zero at $1 \%$ level of significance. 


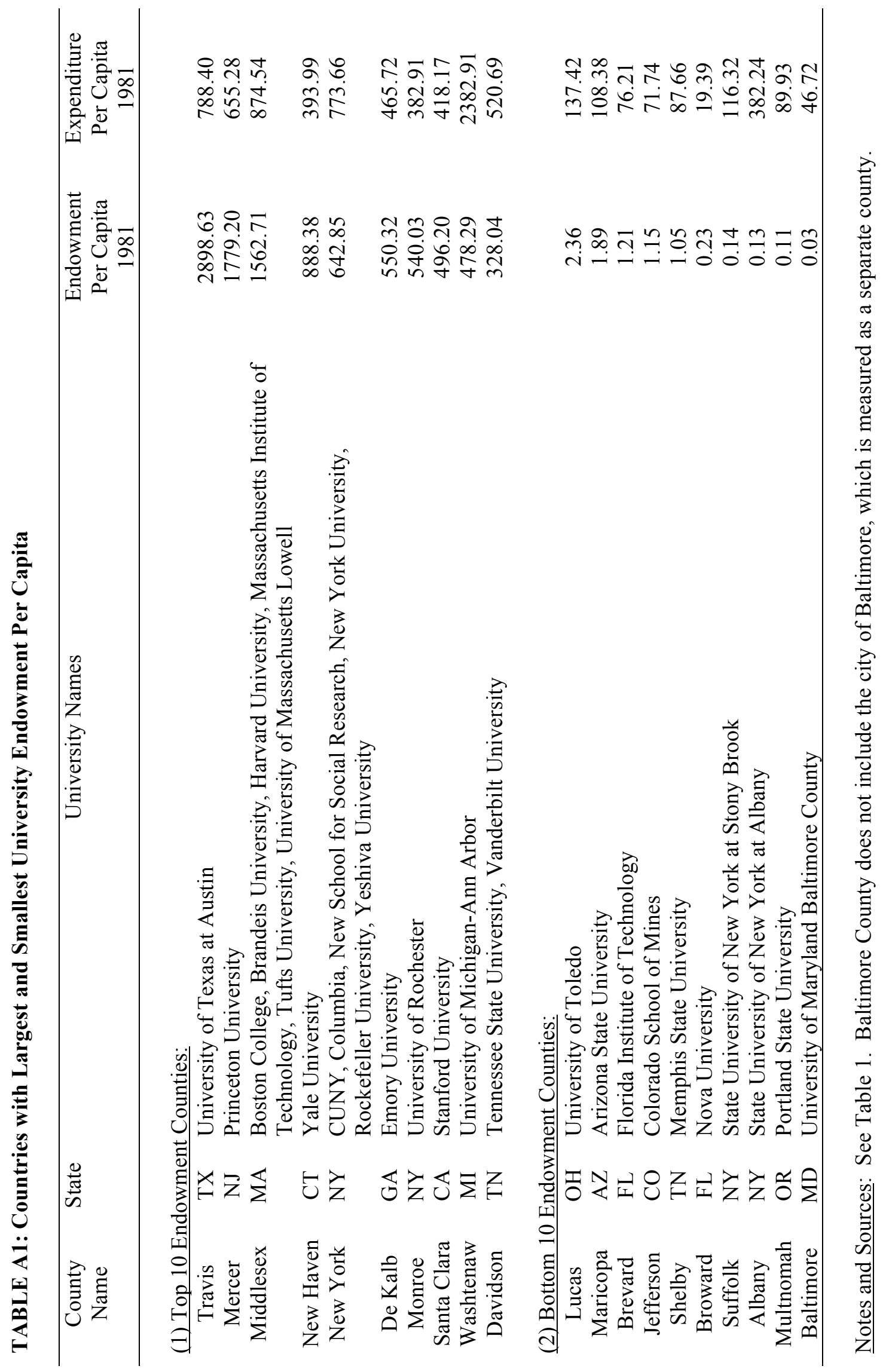




\section{TABLE A2: The Effect of Stock Market Shocks to Endowment Value on University Expenditure: Additional Stock Index Interactions}

Dependent Variable $=\Delta$ University Expenditure $($ period $t)$

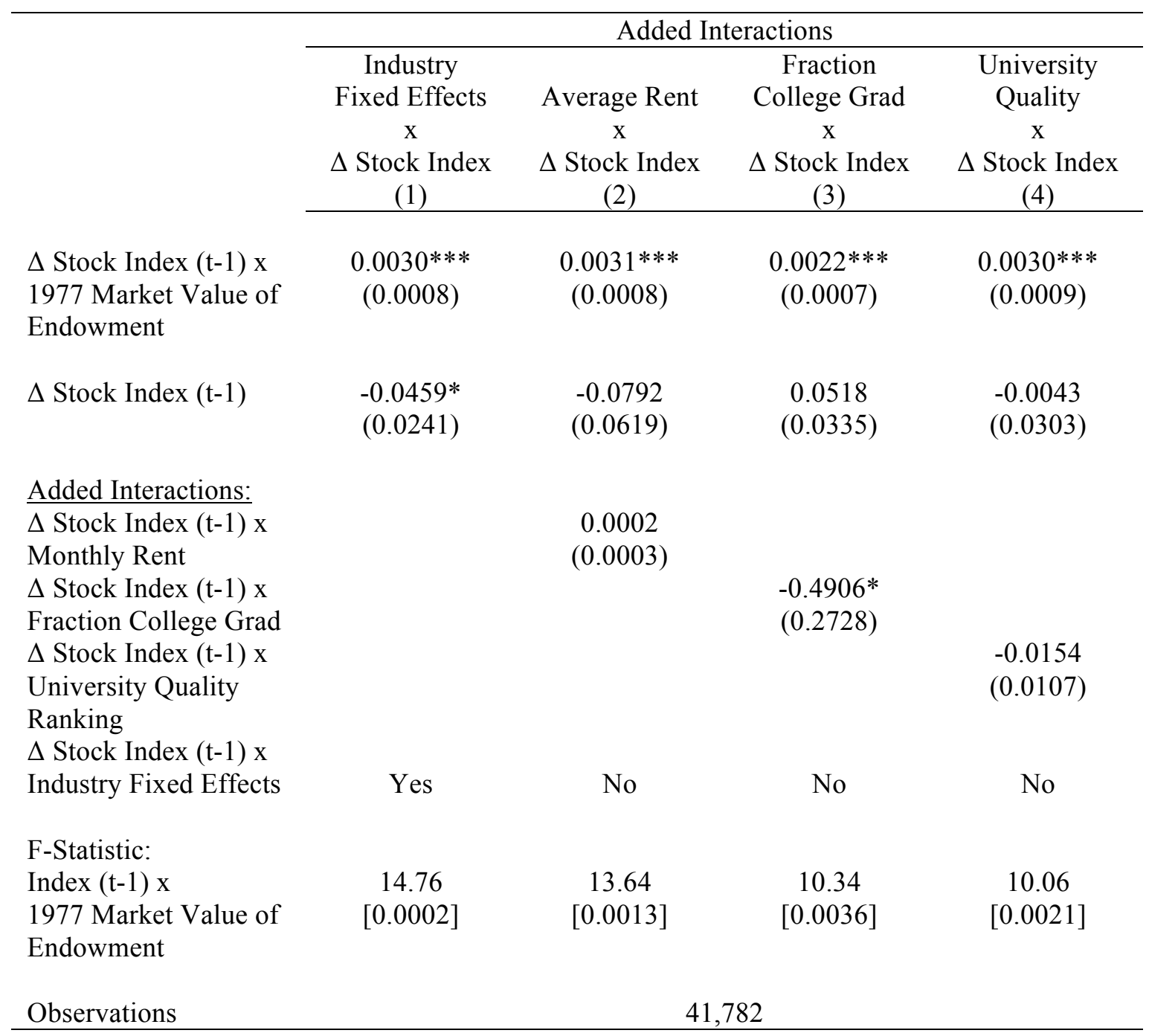

Notes and Sources: See Table 1. The estimates presented are for model (9) in the text. The unit of observation is at the county-industry-year level and the sample is all large university counties. All estimates are weighted by the level of employment in the industry-county cell in 1981. $\Delta$ University Expenditure ( $\mathrm{t}-\mathrm{x}$ ) is measured as spending rate per ' 000 county population. The main entries in columns (1) - (4) are coefficient estimates. All estimates are weighted by the level of employment in the industry-county cell in 1981. The entries in parentheses in columns (1) - (2) are the standard errors of the coefficient estimates clustered at the county level. The entries in the seventh row report the F-Statistic for the test of whether the excluded instruments are zero. The test statistic value is reported as the main entry, and the p-value of test is reported in square brackets.

* indicates significantly different from zero at the $10 \%$ level of significance;

** indicates significantly different from zero at the $5 \%$ level of significance;

$* * *$ indicates significantly different from zero at $1 \%$ level of significance. 